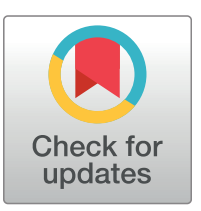

OPEn ACCESS

Citation: Guan Y, Feng M, Min X, Zhou H, Fu Y, Tachibana H, et al. (2018) Characteristics of inflammatory reactions during development of liver abscess in hamsters inoculated with Entamoeba nuttalli. PLoS Negl Trop Dis 12(2): e0006216. https://doi.org/10.1371/journal.pntd.0006216

Editor: Isaura Meza, CINVESTAV, Mexico City, MEXICO

Received: October 2, 2017

Accepted: January 5, 2018

Published: February 8, 2018

Copyright: @ 2018 Guan et al. This is an open access article distributed under the terms of the Creative Commons Attribution License, which permits unrestricted use, distribution, and reproduction in any medium, provided the original author and source are credited.

Data Availability Statement: All relevant data are within the paper and its Supporting Information files.

Funding: This work was supported by National Natural Science Foundation of China (NSFC 81171594 and 81630057) (http://www.nsfc.gov. $\mathrm{cn} /$ ) to XC, and Japan Society for Promotion Science (JSPS KAKENHI JP16H05819) (http:// www.jsps.go.jp) to HT. The funders had no role in study design, data collection and analysis, decision to publish, or preparation of the manuscript.
RESEARCH ARTICLE

\section{Characteristics of inflammatory reactions during development of liver abscess in hamsters inoculated with Entamoeba nuttalli}

\author{
Yue Guan ${ }^{1 \oplus}$, Meng Feng ${ }^{1 \oplus}$, Xiangyang Min ${ }^{1,2}$, Hang Zhou ${ }^{1}$, Yongfeng Fu ${ }^{1}$, \\ Hiroshi Tachibana $^{3 *}$, Xunjia Cheng ${ }^{1,3 *}$
}

1 Department of Medical Microbiology and Parasitology, School of Basic Medical Sciences, Fudan University, Shanghai, China, 2 Department of Clinical Laboratory Medicine, Yangpu Hospital of Tongji University, Shanghai, China, 3 Department of Infectious Diseases, Tokai University School of Medicine, Isehara, Kanagawa, Japan

จ These authors contributed equally to this work.

*xjcheng@shmu.edu.cn (XC); htachiba@ is.icc.u-tokai.ac.jp (HT)

\section{Abstract}

\section{Background}

Entamoeba nuttalli is an intestinal protozoan with pathogenic potential that can cause amebic liver abscess. It is highly prevalent in wild and captive macaques. Recently, cysts were detected in a caretaker of nonhuman primates in a zoo, indicating that $E$. nuttalli may be a zoonotic pathogen. Therefore, it is important to evaluate the pathogenicity of $E$. nuttalli in detail and in comparison with that of E. histolytica.

\section{Methodology/Principal findings}

Trophozoites of E. nuttalli GY4 and E. histolytica SAW755 strains were inoculated into liver of hamsters. Expression levels of proinflammatory factors of hamsters and virulence factors from E. histolytica and E. nuttalli were compared between the two parasites. Inoculations with trophozoites of $E$. nuttalli resulted in an average necrotic area of $24 \%$ in liver tissue in 7 days, whereas this area produced by E. histolytica was nearly $50 \%$. Along with the mild liver tissue damage induced by $E$. nuttalli, expression levels of proinflammatory factors (TNF- $\alpha$, IL-6 and IL-1 $\beta$ ) and amebic virulence protein genes (lectins, cysteine proteases and amoeba pores) in local tissues were lower with $E$. nuttalli in comparison with $E$. histolytica. In addition, M2 type macrophages were increased in E. nuttalli-induced amebic liver abscesses in the late stage of disease progression and lysate of $E$. nuttalli trophozoites induced higher arginase expression than E. histolytica in vitro.

\section{Conclusions/Significance}

The results show that differential secretion of amebic virulence proteins during E. nuttalli infection triggered lower levels of secretion of various cytokines and had an impact on polarization of macrophages towards a M1/M2 balance. However, regardless of the degree of 
Competing interests: The authors have declared that no competing interests exist. macrophage polarization, there is unambiguous evidence of an intense acute inflammatory reaction in liver of hamsters after infection by both Entamoeba species.

\section{Author summary}

Entamoeba nuttalli is the phylogenetically closest protozoan to Entamoeba histolytica and is highly prevalent in macaques. Previous studies have indicated that $E$. nuttalli is virulent in a hamster model. In this study, we compared the immunopathological basis of formation of liver abscess in hamsters between E. nuttalli and E. histolytica. Mild liver tissue damage developed after intrahepatic injection of trophozoites of E. nuttalli, and lower expression levels of genes for host proinflammatory factors and amebic virulence proteins were detected at the edges of liver abscesses induced by E. nuttalli. In addition, alternatively activated macrophages were increased in E. nuttalli-induced liver abscesses in the late stage of disease progression. The lysate of $E$. nuttalli trophozoites also induced higher arginase expression than E. histolytica in vitro. Polarization of macrophages is likely to affect the degree of acute inflammatory reactions in liver in an animal model during $E$. nuttalli infection. Our data reveal new characteristics of abscess formation by E. nuttalli.

\section{Introduction}

The enteric protozoan Entamoeba histolytica causes an estimated 50 million cases of amebic colitis and liver abscess in humans, resulting in 40,000 to 100,000 deaths annually [1-5]. Entamoeba dispar is morphologically indistinguishable from E. histolytica, but is nonpathogenic. E. histolytica and E. dispar are also found in feces of nonhuman primates [6]. Recently, Entamoeba nuttalli, which is phylogenetically closer to E. histolytica than E. dispar, has also been identified in nonhuman primates [7], and there is a high prevalence of E. nuttalli infections in wild and captive macaques, including Macaca mulatta, $M$. fasciculalis, . fuscata, $M$. thibetana and M. sinica, and other nonhuman primates in zoos [8-15]. Most macaques with E. nuttalli infections are asymptomatic, suggesting that the host-parasite relationship in macaques may be commensal in natural infection [12]. More recently, cysts of $E$. nuttalli were detected in a caretaker of nonhuman primates in a zoo [16]. The infected person was asymptomatic, but this finding raises the possibility that $E$. nuttalli is a zoonotic pathogen.

Fatal cases with liver abscess due to $E$. nuttalli have been reported in Abyssinian colobus and Geoffroy's spider monkey in a zoo [17, 18], and inoculation of $E$. nuttalli trophozoites in liver of hamsters causes formation of abscesses and is lethal in some cases [7, 10, 12]. Hamsters inoculated with E. nuttalli are weakened and have decreased body weight. The liver lesions produced by $E$. nuttalli trophozoites are characterized by extensive necrosis associated with inflammatory reactions $[7,10]$. These histological changes are similar to those caused by E. histolytica trophozoites, suggesting similar pathological mechanisms of tissue damage $[7,10,19$, 20]. However, E. histolytica infection in liver generally results in large single abscesses [1,21], whereas E. nuttalli infection in hamsters induces small multiple abscesses [7]. Thus, the detailed mechanisms of how hosts with $E$. nuttalli develop a different pathogenic manifestation from that in E. histolytica infection are poorly defined.

E. nuttalli is as virulent as E. histolytica in animal models, but it remains unclear whether $E$. nuttalli is virulent in humans. These findings, coupled with in vivo observations that E. nuttalli causes histological lesions in similar conditions and has few sequence differences in some 
important genes $[7,14]$ in comparison with E. histolytica, have reinforced the idea that E. nuttalli is incapable of generating human lesions because of the host specificity of E. nuttalli and E. histolytica parasites. Therefore, it is important to evaluate the pathogenicity of E. nuttalli in comparison with that of E. histolytica to examine the molecular basis of the pathophysiology of amebic liver abscess (ALA) formation. In this study, expression levels of proinflamatory factors in hamsters and virulence factors from E. histolytica and E. nuttalli were compared between these parasites. The histopathological and immunopathological analyses of ALA provide valuable information on the pathogenicity of E. nuttalli.

\section{Methods}

\section{Ethics statement}

All animal experiments were performed in strict accordance with the Regulations for the Administration of Affairs Concerning Experimental Animals (1988.11.1) and were approved by the Institutional Animal Care and Use Committee (IACUC) of our institutions (Permit Numbers 20110307-051 and 20160225-097). All efforts were made to minimize suffering.

\section{Amebas and mammalian cells}

Trophozoites of E. histolytica SAW755CR and E. nuttalli GY4 strains were grown under axenic conditions at $36.5^{\circ} \mathrm{C}$ in YIMDHA-S medium [22] containing $15 \%(\mathrm{v} / \mathrm{v})$ heat-inactivated adult bovine serum. Trophozoites were harvested during the logarithmic growth phase (48 to $72 \mathrm{~h}$ ) by chilling on ice for $5 \mathrm{~min}$. RAW264.7 cells were cultured in DMEM (Thermo) supplemented with $10 \%$ fetal bovine serum (FBS) (Thermo), $100 \mathrm{U} / \mathrm{ml}$ penicillin, and $100 \mu \mathrm{g} / \mathrm{ml}$ streptomycin. CHO-K1 cells were cultured in Ham's F12 nutrient medium (Thermo) supplemented with $10 \% \mathrm{FBS}, 100 \mathrm{U} / \mathrm{ml}$ penicillin, and $100 \mu \mathrm{g} / \mathrm{ml}$ streptomycin. The mammalian cells were grown in a $37^{\circ} \mathrm{C}$ incubator with $5 \% \mathrm{CO}_{2}$.

\section{Animal model for ALA}

Six-week-old male hamsters were obtained from Shanghai Songlian Experimental Animal Factory. ALA was induced by direct inoculation of $1 \times 10^{6}$ axenic trophozoites of $E$. histolytica SAW755CR strain or E. nuttalli GY4 strain into liver, as previously described [23].

\section{Pathologic evaluation using liver tissue sections}

After intrahepatic inoculation of trophozoites, hamsters were euthanized at $3 \mathrm{~h}, 6 \mathrm{~h}, 12 \mathrm{~h}, 24 \mathrm{~h}$, $48 \mathrm{~h}, 72 \mathrm{~h}$ and $168 \mathrm{~h}$ post-inoculation. At each time point, 6 to 7 hamsters were used. Liver tissues were harvested and fixed in $4 \%$ paraformaldehyde followed by paraffin embedding. Sections were stained with hematoxylin and eosin (HE) or periodic acid-Schiff (PAS) for histopathology [7]. Tissue damage and inflammatory cell infiltration were quantified in high quality images $(2560 \times 1920$ pixels) captured using a Nikon light microscope. Areas of leukocyte infiltration and liver necrosis were measured using Image-Pro Plus 4.5.1 software (Media Cybernetics). Areas of interest are expressed as a percentage of the total tissue area.

\section{Analysis of cytokines by immunohistochemistry and quantitative real-time PCR}

Immunohistochemical staining was performed as described elsewhere [24]. Briefly, paraformaldehyde-fixed liver sections were deparaffinized, rehydrated by standard protocols and incubated overnight at $4^{\circ} \mathrm{C}$ with rabbit anti mouse IFN- $\gamma$, TNF- $\alpha$, IL-1 $\beta$ and IL-6 polyclonal antibodies (Abcam). The slides were subsequently incubated with horseradish peroxidase- 
labeled goat anti-rabbit immunoglobulin and then with chromogen substrate $\left(3,3^{\prime}\right.$-diaminobenzidine) for $2 \mathrm{~min}$ before counterstaining with hematoxylin. The cytokine score (intensity area/total image area) was determined in areas of leukocyte infiltration using Image-Pro Plus 4.5.1 software (Media Cybernetics). Each cytokine score was determined by counting more than 50 high-power fields $(\times 20)$.

Gene expression of IFN- $\gamma$, TNF- $\alpha$, IL-1 $\beta$, IL-4, IL-6, IL-10, nitric oxide synthase (iNOS), arginine enzyme I (Arg-1) and mannose receptor I (MRC-I) in liver tissues was examined by quantitative real-time PCR (qRT-PCR) using the primers listed in Table 1 [22, 25-26]. Briefly, total RNA $(1 \mu \mathrm{g})$ of tissue from the edge of a liver abscess was purified with an RNeasy Plus Mini kit (Qiagen). cDNA was synthesized with a Primescript first-strand cDNA synthesis kit (Takara) using oligo(dT) primers. qRT-PCR was carried out in a final reaction volume of $20 \mu \mathrm{l}$ on an ABI 7500 Real-time PCR system (Applied Biosystems). Reactions were performed in a 96-well plate with SYBR Premix Ex Taq (Takara, Japan) containing primers listed in Table 1. The amplification cycling conditions were as follows: $30 \mathrm{~s}$ at $95^{\circ} \mathrm{C}$ and 40 cycles of $5 \mathrm{~s}$ at $95^{\circ} \mathrm{C}$ and $35 \mathrm{~s}$ at $60^{\circ} \mathrm{C}$. Analysis by qRT-PCR of gene expression was conducted during the log phase of product accumulation, during which Ct values correlated linearly with relative DNA copy numbers. Each experiment was performed at least three times.

\section{Analysis of gene expression of amebic virulence proteins by qRT-PCR}

Gene expression of heavy subunit of galactose/N-acetylgalactosamine lectin $(\mathrm{Hgl})$, intermediate subunit of galactose/ $\mathrm{N}$-acetylgalactosamine lectin (Igl), cysteine proteinase 2 (CP2), cysteine proteinase 5 (CP5), amoebapore A (AP-A), and amoebapore B (AP-B) of Entamoeba trophozoites in ALA tissues were examined using the same RNA samples extracted from tissue at the edge of a liver abscess. Genes of virulence proteins of $E$. nuttalli GY4 strain were amplified and sequenced (S1 Text). Primers for these genes were designed using the identical sequence regions of E. histolytica SAW755CR strain and E. nuttalli GY4 strain, and are listed in Table 1. The primers for $\mathrm{Hgl}$ and Igl used in this study can amplify all known subtypes of $\mathrm{Hgl}$ and Igl genes. Reactions were performed as described above. Each experiment was performed at least three times.

\section{In vitro stimulation of macrophages by trophozoite lysates of amebas}

To assess whether secretory proteins from E. histolytica and $E$. nuttalli cause polarization of macrophages, trophozoites were first incubated with $\mathrm{CHO}$ cells and then lysed. RAW264.7 cells were stimulated with the lysates of ameba trophozoites. Briefly, CHO-K1 cells $\left(10^{6}\right)$ were cultured in a $35-\mathrm{mm}$ dish (Costar), and then $5 \times 10^{5}$ trophozoites were added and coincubated for $30 \mathrm{~min}$. Trophozoites were then harvested, and lysed by repeated freezing and thawing of $10^{6}$ trophozoites per $\mathrm{ml}$ in PBS. After centrifugation at 20,000 $\mathrm{g}$ for $10 \mathrm{~min}$, trophozoite lysates were used to stimulate RAW264.7 cells $\left(5 \times 10^{5}\right)$ in 24 -well culture plates (Costar) overnight. The cells were stimulated with trophozoite lysates, LPS ( $1 \mu \mathrm{g} / \mathrm{ml}$ final conc.) (Sigma) or PBS. After incubation for $6 \mathrm{~h}, 12 \mathrm{~h}, 24 \mathrm{~h}$ and $48 \mathrm{~h}$, culture supernatants of RAW264.7 cells were assayed for cytokines and NO production. Cells were collected and frozen for measurement of arginase activity and expression of iNOS and Arg-1 genes by qRT-PCR. Each experiment was performed at least three times.

\section{Determination of expression of iNOS and Arg-1 genes by qRT-PCR}

Total RNA $(1 \mu \mathrm{g})$ of treated RAW264.7 cells was purified with an RNeasy Plus Mini kit (Qiagen). cDNA was synthesized with a Primescript first-strand cDNA synthesis kit (Takara) using oligo(dT) primers. Gene expression of iNOS and Arg-1 was examined by qRT-PCR using the 
Table 1. Primers used in this study.

\begin{tabular}{|c|c|c|}
\hline \multirow[t]{2}{*}{ Hamster-IFN- $\gamma$} & S & CCATCCAGAGGAGCATAG \\
\hline & AS & CAGCACCGACTTCTTTTC \\
\hline \multirow[t]{2}{*}{ Hamster-TNF- $\alpha$} & S & CCTCCTGTCCGCCATCAAG \\
\hline & AS & CACTGAGTCGGTCACCTTTC \\
\hline \multirow[t]{2}{*}{ Hamster-IL-6 } & S & AGGACACTACTCCCAACAG \\
\hline & AS & GAGGCATCCATCATTTATT \\
\hline \multirow[t]{2}{*}{ Hamster-IL-1 $\beta$} & S & AATGCCTCGTGCTGTCTG \\
\hline & AS & TTGTTGCTTGTTTCTCCCT \\
\hline \multirow[t]{2}{*}{ Hamster-IL-4 } & S & TGCACCGAGATGGTCGTAC \\
\hline & AS & GTCTTTGAGAACCCTGGAAT \\
\hline \multirow[t]{2}{*}{ Hamster-IL-10 } & S & CAACTGCAGCGCTGTCATCGATTT \\
\hline & AS & ATGGCCTTGAAGACGCCTTTCTCT \\
\hline \multirow[t]{2}{*}{ Hamster-iNOS } & S & GCCTGCCGTAGCCAACAT \\
\hline & AS & CAGAAGTCTCGAACGCCAAT \\
\hline \multirow[t]{2}{*}{ Hamster-Arg-1 } & S & GCCTTTGCTGATGTCCCT \\
\hline & AS & GCTTCCAACTGCCATACTG \\
\hline \multirow[t]{2}{*}{ Hamster-MRC1 } & $\mathrm{S}$ & AGATAAACTCCAAGTCTGCCTTAA \\
\hline & AS & ACTGCCAACCACTGCTGAAA \\
\hline \multirow[t]{2}{*}{ Hamster- $\beta$-actin } & S & TCTACAACGAGCTGCG \\
\hline & AS & CAATTTCCCTCTCGGC \\
\hline \multirow[t]{2}{*}{$\mathrm{Hgl}$} & $\mathrm{S}$ & TGTGGTGGAGATTCTACA \\
\hline & AS & CATCACCAACTGCTTGAA \\
\hline \multirow[t]{2}{*}{ Igl } & S & AAATGTTCTTGTGGTGATG \\
\hline & AS & GTGCACAACTTTTCTTCTT \\
\hline \multirow[t]{2}{*}{$\mathrm{CP} 2$} & S & ATCCAAGCACCAGAATCAGT \\
\hline & AS & TTCCTTCAAGAGCTGCAAGT \\
\hline \multirow[t]{2}{*}{ CP5 } & S & AAAGAATGTTCATCAACTCAGCTT \\
\hline & AS & TTAAGCATCAGCAACCCCAACTGG \\
\hline \multirow[t]{2}{*}{ AP-A } & S & TAATCTTCGCTGTTGCTTT \\
\hline & AS & TCAGCTCCCTTAGTGGTAA \\
\hline \multirow[t]{2}{*}{ AP-B } & S & TGCTATTGCCTTTGCTGC \\
\hline & AS & TTCGCAAACAACGACTGG \\
\hline \multirow[t]{2}{*}{ Eh-actin } & S & GCACTTGTTGTAGATAATGGATCAGGAATG \\
\hline & AS & ACCCATACCAGCCATAACTGAAACG \\
\hline
\end{tabular}

primers listed in Table 1. Reactions were performed as described above. Each experiment was performed at least three times.

\section{Measurement of NO production by Griess assay}

A Griess assay was performed using $20 \mu \mathrm{l}$ of culture supernatant of RAW264.7 cells mixed with $30 \mu \mathrm{l}$ of distilled water and $50 \mu \mathrm{l}$ of Griess reagent (Sigma). Absorbance was measured at $548 \mathrm{~nm}$ in a microplate reader $[27,28]$. Experiments were performed at least three times.

\section{Quantification of arginase activity}

Arginase activity in cell lysates was measured in RAW264.7 cells that were harvested and lysed with mammalian tissue lysis/extraction reagent (Sigma) for $15 \mathrm{~min}$ on a shaker and centrifuged at 13,000 g for $10 \mathrm{~min}$ to remove insoluble material. Sample supernatant $(20 \mu \mathrm{l})$ was 
added to a well of a 96-well plate, $10 \mu \mathrm{l}$ of substrate buffer was added, and the mixture was incubated at $37^{\circ} \mathrm{C}$ for $120 \mathrm{~min}$ for arginine hydrolysis. The reaction was stopped with $200 \mu \mathrm{l}$ of urea in each well at room temperature for $30 \mathrm{~min}$. Absorbance was measured at $430 \mathrm{~nm}$ in a microplate reader. One unit of arginase is the amount of enzyme that converts $1.0 \mathrm{mM}$ of Larginine to ornithine and urea per minute at $\mathrm{pH} 9.5$ and $37^{\circ} \mathrm{C}$. Each experiment was performed at least three times.

\section{Proliferation assay of RAW264.7 cells using a cell counting test}

To assess whether secretory proteins from E. histolytica and E. nuttalli cause proliferation of macrophages, a cell proliferation assay was performed. RAW264.7 cells $\left(5 \times 10^{4}\right)$ were cultured in 96-well culture plates (Costar) overnight. Cells were stimulated with $5 \mu \mathrm{l}$ of PBS, trophozoite lysates or LPS ( $1 \mu \mathrm{g} / \mathrm{ml}$ final). CCK-8 reagent (Dojindo) was added to each well at $4 \mathrm{~h}, 10 \mathrm{~h}, 22$ $\mathrm{h}$ or $46 \mathrm{~h}$, and optical density (OD) was measured at $450 \mathrm{~nm}$ using a microplate reader (Biorad) at $6 \mathrm{~h}, 12 \mathrm{~h}, 24 \mathrm{~h}$ or $48 \mathrm{~h}$. Each experiment was performed at least three times.

\section{Analysis of cytokine secretion by Luminex multiplex immunoassay}

A Luminex multiplex immunoassay was performed to determine the concentrations of inflammatory cytokines using a customized Milliplex Mouse Cytokine/Chemokine Magnetic Bead Panel (Merck Millipore) for IL-1 $\beta$, IL-6 and TNF- $\alpha$. Briefly, $25 \mu$ l of cell supernatant, control or standard was added to a 96 -well plate containing $25 \mu \mathrm{l}$ of capture antibody-coated, fluorescent-coded beads. Biotinylated detection antibodies and streptavidin-PE were added to the plate after the appropriate incubation periods. After the last washing step, $150 \mu \mathrm{l}$ of sheath fluid was added to the wells, and the plate was incubated and read on a Luminex100 instrument. Five-PL regression curves were used to plot standard curves for all analytes with xPonent 3.1 software by analyzing the bead median fluorescence intensity. Results are expressed in $\mathrm{pg} / \mathrm{ml}$. Samples with quantification below the detection limit were registered as "zero" and samples above the quantification limit of the standard curve were given the value equal to the highest value of the curve. Each experiment was performed at least three times.

\section{Statistical analysis}

Statistical analyses were performed using IBM SPSS (ver. 20, SPSS Statistics/IBM Corp., Chicago, IL, USA). qRT-PCR data were analyzed by two-tailed Mann-Whitney U test. Other data were analyzed with a two-tailed Student t-test. $P<0.05$ was considered significant in all analyses.

\section{Results}

\section{Liver tissue injury and inflammation induced by trophozoites}

After inoculation of trophozoites into hamster liver, both E. histolytica SAW755 and E. nuttalli GY4 caused ALA, with a clear boundary between the abscess and normal tissue. The main area of inflammatory cell infiltration and living trophozoites was located at the edge of the abscess. At $3 \mathrm{~h}$ post-inoculation, inflammatory cell infiltration (mainly neutrophils) was observed (Figs 1A, S1-S3), and then infiltration of inflammatory cells increased in liver tissues. These cells were mainly monocytes and macrophages. A clear liver abscess was seen from 24 to $168 \mathrm{~h}$ with E. histolytica and 48 to $168 \mathrm{~h}$ with E. nuttalli (Fig 1B). ALA areas increased to nearly $50 \%$ with E. histolytica at $168 \mathrm{~h}$, whereas the average ALA area was only $24 \%$ at $168 \mathrm{~h}$ with E. nuttalli. These results indicate that mild liver tissue damage was induced by $E$. nuttalli GY4 strain. Similarly, the area of inflammatory cell infiltration with $E$. nuttalli was smaller than that with $E$. 

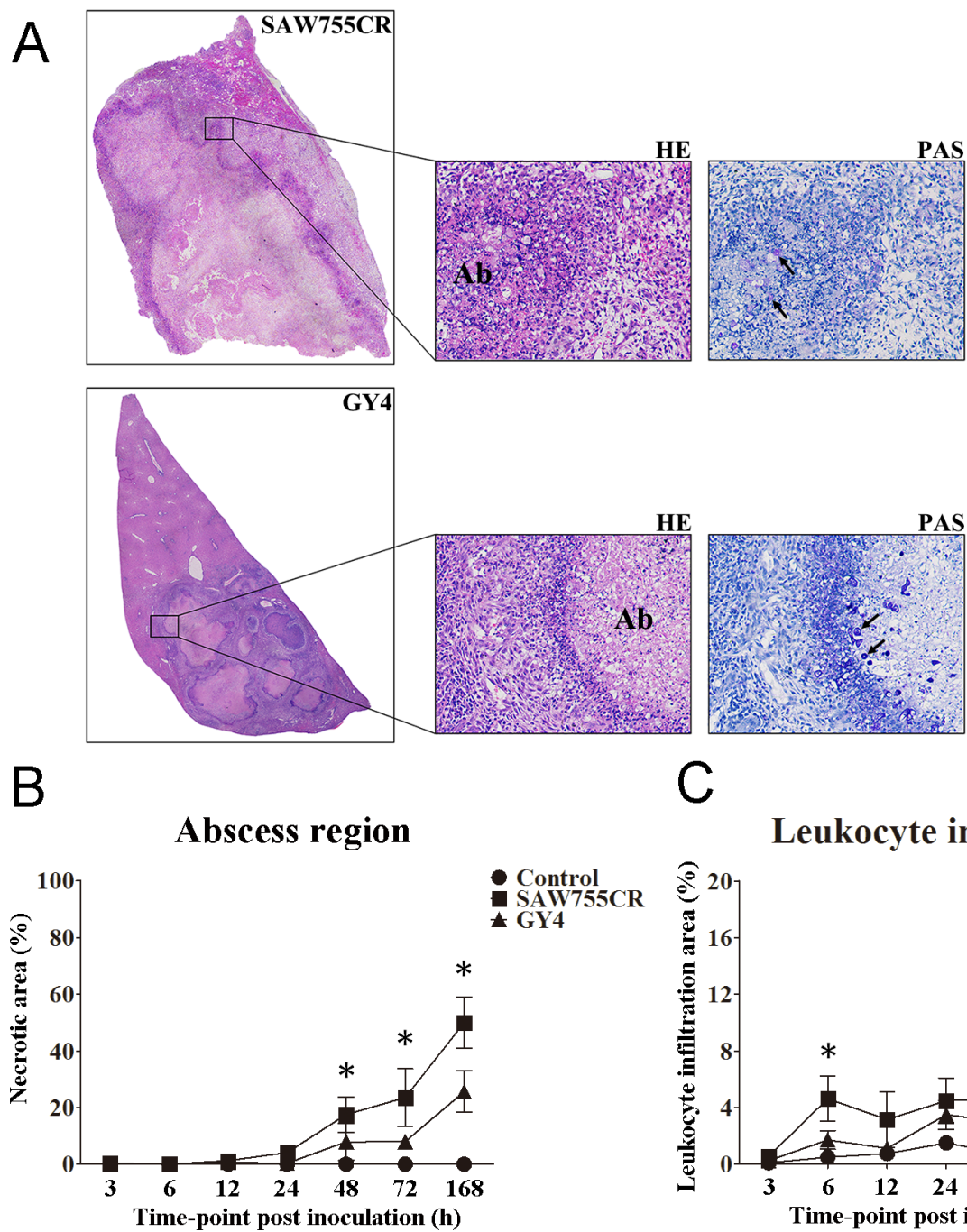

C

\section{Leukocyte infiltration}

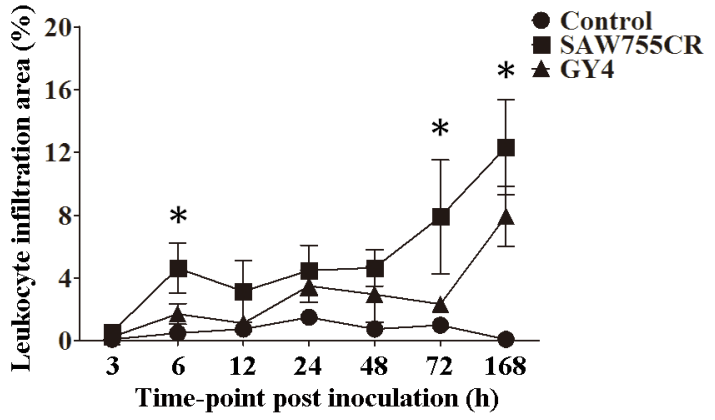

Fig 1. Histological features of liver in hamsters inoculated with trophozoites of $E$. histolytica or E. nuttalli. (A) Tissue section stained with hematoxylin and eosin (HE) and periodic acid-Schiff (PAS). Hamsters were inoculated with $1 \times 10^{6}$ trophozoites of $E$. histolytica SAW755CR strain or E. nuttalli GY4 strain. Seven days after inoculation, multiple PAS-positive trophozoites (arrows) and inflammatory cells were observed in peripheral areas of necrosis $(\mathrm{Ab}) .(\mathrm{B}, \mathrm{C})$ Quantification of abscess region (B) and leukocyte infiltration region (C) in liver sections. Regions were evaluated in each slide of livers from hamsters (6 to 7 in each group) at different times and analyzed using Image-Pro Plus 4.5.1. Areas of interest are expressed as the percentage of the total tissue area. ${ }^{*} \mathrm{P}<0.05$ by two-tailed Student t-test.

https://doi.org/10.1371/journal.pntd.0006216.g001

histolytica at each time point. At $168 \mathrm{~h}$, the inflammatory cell infiltration area was significantly lower with E. nuttalli (7\%) than with E. histolytica (12\%) (Fig 1C).

\section{Increased secretion of proinflammatory cytokines in liver tissues during ALA formation}

To evaluate expression of cytokines during ALA formation by E. nuttalli trophozoites, hamster livers were used for immunohistochemistry at different time points, and expression levels of IFN- $\gamma$, TNF- $\alpha$, IL- 6 and IL- $1 \beta$ in liver abscesses were analyzed. The control group had low levels of these cytokines (Fig 2A) at each time point, whereas areas positive for TNF- $\alpha$, IL- 6 and IL-1 $\beta$ in liver were increased after inoculation with E. histolytica SAW755CR (Fig 2B-2E). 
A

$168 \mathrm{~h}$

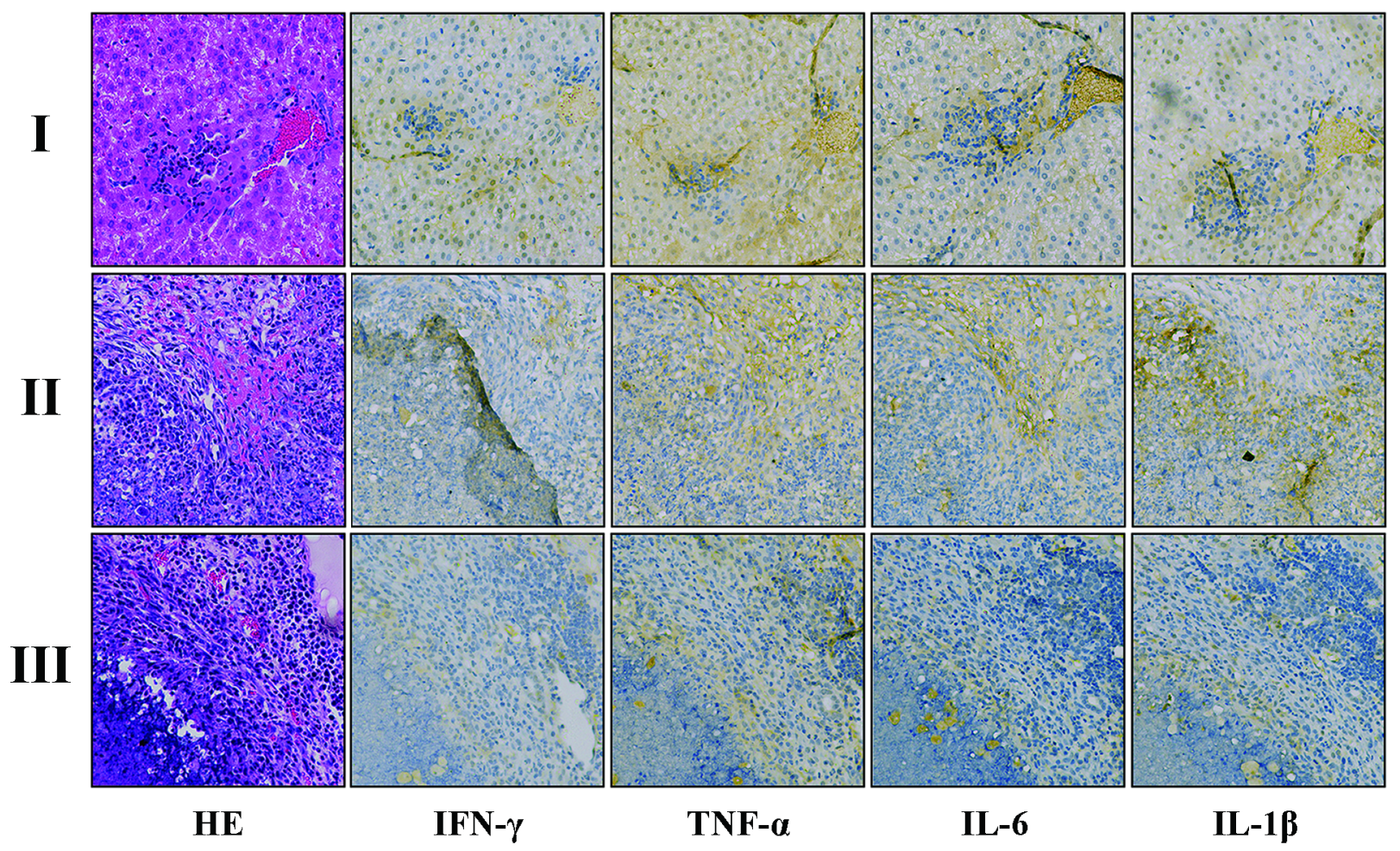

B

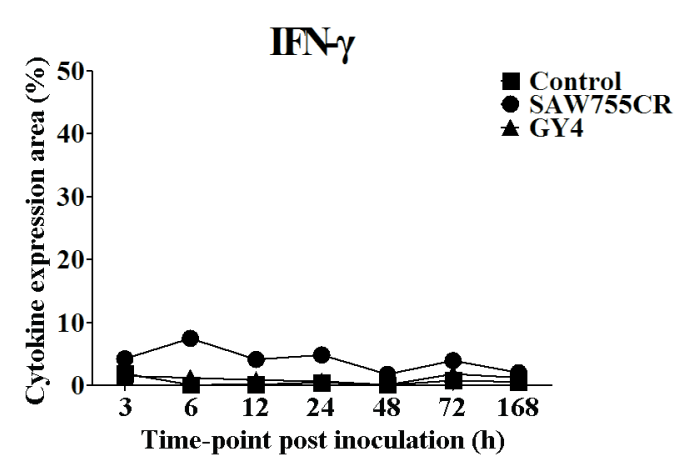

D

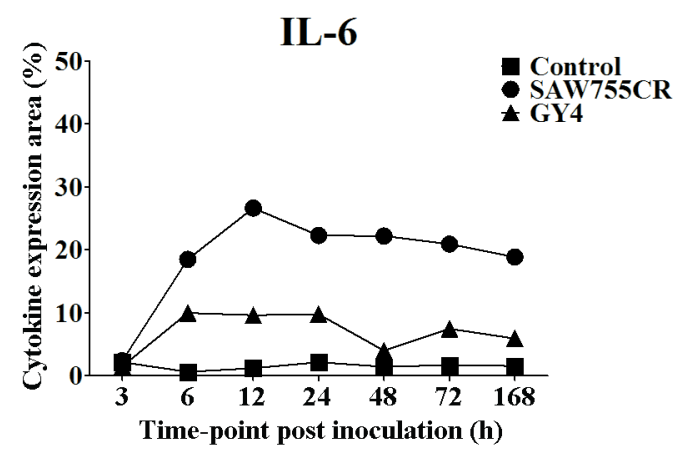

C

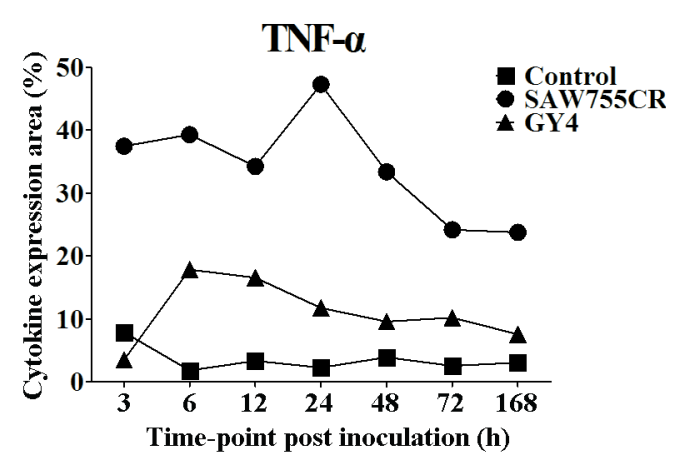

$\mathbf{E}$

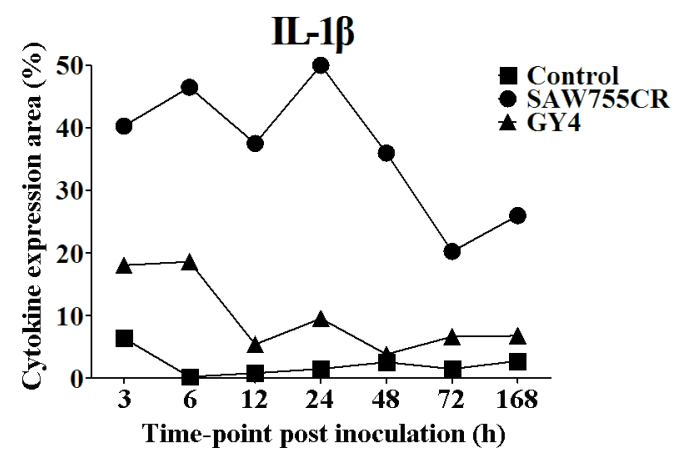

Fig 2. Production of IFN- $\gamma$, TNF- $\alpha$, IL-1ß and IL-6 in ALA of hamsters. (A) Immunohistochemical staining of liver sections. Liver of hamsters was inoculated with $1 \times 10^{6}$ of trophozoites from E. histolytica SAW755CR strain or E. nuttalli GY4 strain. Seven days later, the liver section was stained immunohistochemically with polyclonal antibodies for IFN- $\gamma$, TNF- $\alpha$, IL-1 $\beta$ and IL-6. I: Control group, II: SAW755CR group, III: GY4 group. (B-E) Cytokine scores (positive area/total image area) for IFN- $\gamma(B)$, TNF- $\alpha$ (C), IL-1 $\beta$ (D) and IL-6 (E) in liver sections of hamsters at different times were determined in areas of leukocyte infiltration using Image-Pro Plus 4.5.1. Each cytokine score is the average of counting more than 50 high-power fields $(\times 20)$.

https://doi.org/10.1371/journal.pntd.0006216.g002 
These areas were also increased in liver inoculated with $E$. nuttalli GY4, but to a lesser extent compared with E. histolytica (Fig $2 \mathrm{C}-2 \mathrm{E}$ ). These results indicate a smaller increase in expression of proinflammatory factors (TNF- $\alpha$, IL- 6 and IL-1 $\beta$ ) in local tissues inoculated with $E$. nuttalli GY4. Little IFN- $\gamma$ was detected in liver tissue after inoculation of either strain.

To quantify the changes in cytokines during ALA formation, qRT-PCR was used to amplify IFN- $\gamma$, TNF- $\alpha$, IL-6, IL- $1 \beta$, IL- 4 and IL-10 genes, with $\beta$-actin amplified as a reference. The results for expression levels of TNF- $\alpha$, IL- 6 and IL- $1 \beta$ in tissue at the edge of liver abscesses were similar to the immunohistochemistry data. At most time points, IL- 6 and IL- $1 \beta$ increased significantly with E. histolytica and E. nuttalli (Fig 3). qRT-PCR showed that expression of

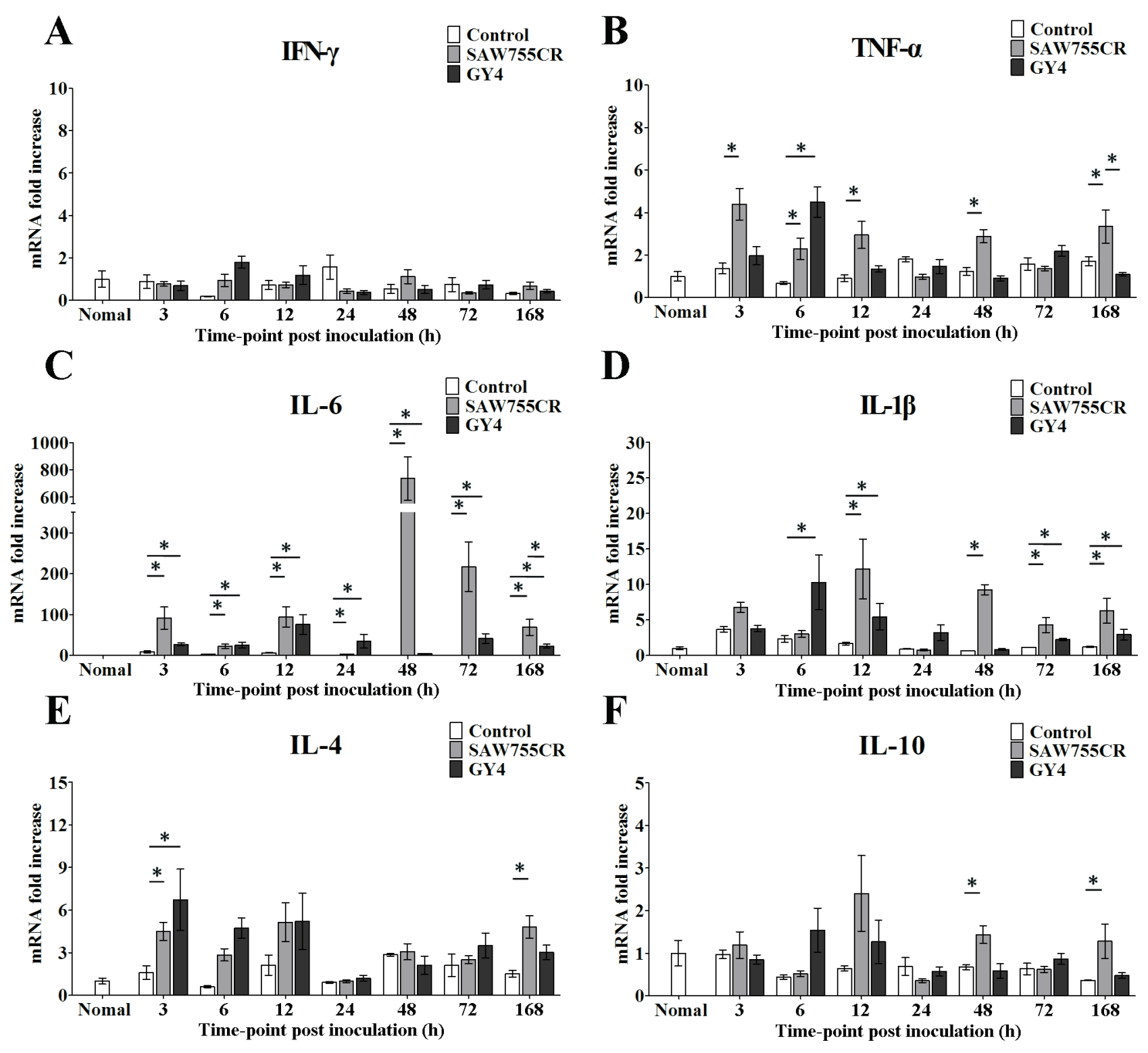

Fig 3. Quantitative real-time PCR assay of gene expression of IFN- $\gamma$ (A), TNF- $\alpha$ (B), IL-6 (C), IL-1ß (D), IL-4 (E) and IL-10 (F) in ALA of hamsters. Expression levels of cytokine genes in liver tissues from hamsters inoculated with culture medium or $1 \times 10^{6}$ trophozoites of E. histolytica SAW755CR strain or E. nuttalli GY4 strain are shown as $2-\Delta \Delta \mathrm{Ct}$ of the target gene relative to $\beta$-actin and normalized using the corresponding values in normal hamster. Y axes are numbers correspond to the fold increase over 1.0, assigned to normal hamster. Error bars represent standard errors of the mean calculated from three independent replicates. The abscissa shows the time post-inoculation. ${ }^{*} \mathrm{P}<0.05$.

https://doi.org/10.1371/journal.pntd.0006216.g003 
TNF- $\alpha$, IL-6 and IL- $1 \beta$ with E. nuttalli GY4 was lower than with E. histolytica SAW755CR at $48 \mathrm{~h}, 72 \mathrm{~h}$ and $168 \mathrm{~h}$, and expression of IL-6 was particularly significantly lower.

\section{Polarization of macrophages in ALA development}

Macrophages are immune effector cells that play an important role in ALA development. Expression of iNOS and Arg-1 genes was analyzed by qRT-PCR to examine differences in macrophage polarization in liver abscesses induced by the two species of Entamoeba trophozoites. Expression of iNOS rose rapidly after inoculation, whereas that of Arg-1 decreased (Fig $4 \mathrm{~A}$ and $4 \mathrm{~B})$. MRC-I is a highly expressed surface receptor on M2 macrophages, and expression levels of MRC-I and Arg- 1 changed similarly in qRT-PCR. In the early stage of ALA formation, MRC-I expression increased in all damaged liver tissue (including in the control group). The MRC-I level with E. nuttalli GY4 continued to increase at $72 \mathrm{~h}$ and $168 \mathrm{~h}$, but did not rise further in the control group or with E. histolytica SAW755CR (Fig 4C). The higher iNOS/Arg1 ratio (macrophage polarization M1/M2) at $72 \mathrm{~h}$ and $168 \mathrm{~h}$ suggests macrophage polarization toward M1 with E. histolytica SAW755CR, but toward a M1/M2 balance with E. nuttalli GY4 at $168 \mathrm{~h}$ (Fig 4D). These results suggest that M2 macrophages increased at $168 \mathrm{~h}$ after inoculation of the GY4 strain, and the milder liver tissue damage caused by E. nuttalli GY4 strain might be attributable to the increase in these macrophages.
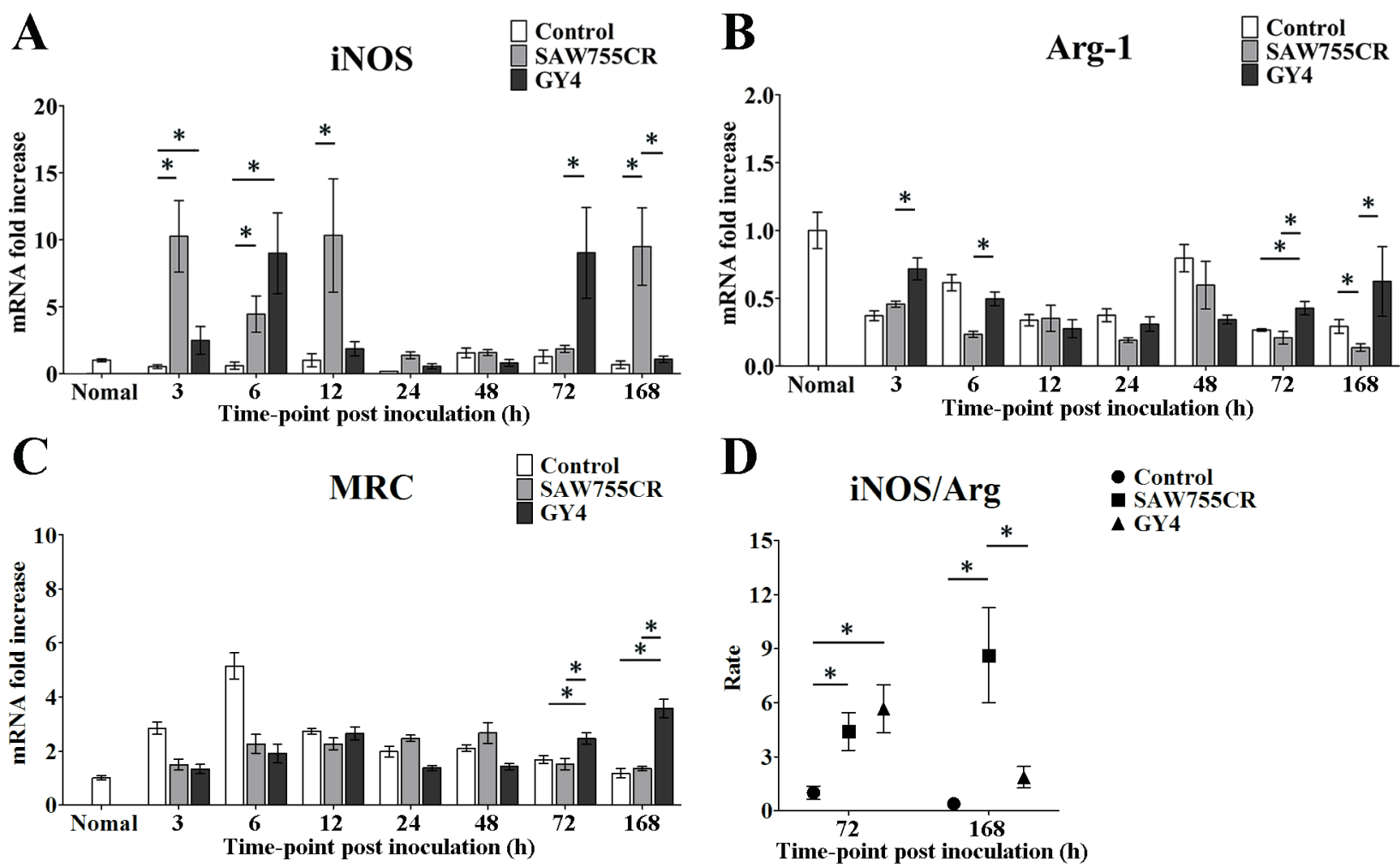

Fig 4. Quantitative real-time PCR assays of expression of iNOS (A), Arg-1 (B) and MRC-I (C) and iNOS/Arg-1 mRNA ratio (D) in ALAs in hamsters. Expression levels of cytokine genes in liver tissues from hamsters inoculated with culture medium, $1 \times 10^{6}$ E. histolytica SAW755CR strain or E. nuttalli GY4 strain trophozoites are shown as $2-\Delta \Delta \mathrm{Ct}$ of the target gene relative to $\beta$-actin and normalized with the corresponding values in normal hamster. $\mathrm{Y}$ axes in $\mathrm{A}$ to $\mathrm{C}$ are numbers correspond to the fold increase over 1.0, assigned to normal hamster. The iNOS/Arg-1 mRNA ratio in hamsters inoculated with trophozoites of E. histolytica SAW755CR or E. nuttalli GY4 is compared with that in controls at $72 \mathrm{~h}$ and $168 \mathrm{~h}$ postinoculation. Error bars are standard errors of the mean calculated from three independent replicates. The abscissa shows the time post-inoculation. ${ }^{*} \mathrm{P}<0.05$.

https://doi.org/10.1371/journal.pntd.0006216.g004 


\section{Expression of virulence protein genes of amebas in ALA development}

To compare changes of virulence proteins with the two Entamoeba species during ALA progression, qRT-PCR was performed to examine expression levels of Hgl, Igl, CP-2, CP-5, AP-A and AP-B genes. There were significant increases in $\mathrm{Hgl}$ (2- to 5-fold), CP2 (5- to 16-fold), CP5 (2- to 11-fold), AP-A (2- to 3-fold) and AP-B (2- to 7-fold) after inoculation in hamster liver (Fig 5). There were few differences between the expression levels of virulence protein genes of E. histolytica and E. nuttalli in vitro; only the CP5 level was half in E. nuttalli compared to E. histolytica (Fig 5D). However, significantly lower expression of CP2, CP5, AP-A and AP-B of E. nuttalli was found at $168 \mathrm{~h}$, and this lower level of virulence proteins in vivo may contribute to the milder liver tissue damage caused by E. nuttalli GY4.

\section{Polarization of RAW264.7 cells after in vitro stimulation with trophozoite lysates}

To study whether secretory proteins of Entamoeba play an important role in polarization of macrophages, in vitro stimulation of mice macrophage RAW264.7 cells was performed, and expression of iNOS and Arg-1 was analyzed by qRT-PCR. The levels of both of these genes rose rapidly after stimulation with trophozoite lysates of E. histolytica or E. nuttalli. Lysate of $E$. histolytica induced significantly higher iNOS expression than that of E. nuttalli at $48 \mathrm{~h}$ (1334-fold vs. 627-fold compared to PBS). In contrast, lysate of E. nuttalli induced higher Arg1 expression than E. histolytica (122-fold vs. 61-fold compared to PBS) (Fig 6A and 6B).

To examine the effects of secretory proteins of Entamoeba on NO production, RAW264.7 cells were stimulated with PBS, trophozoite lysate of E. histolytica or E. nuttalli, and LPS. A
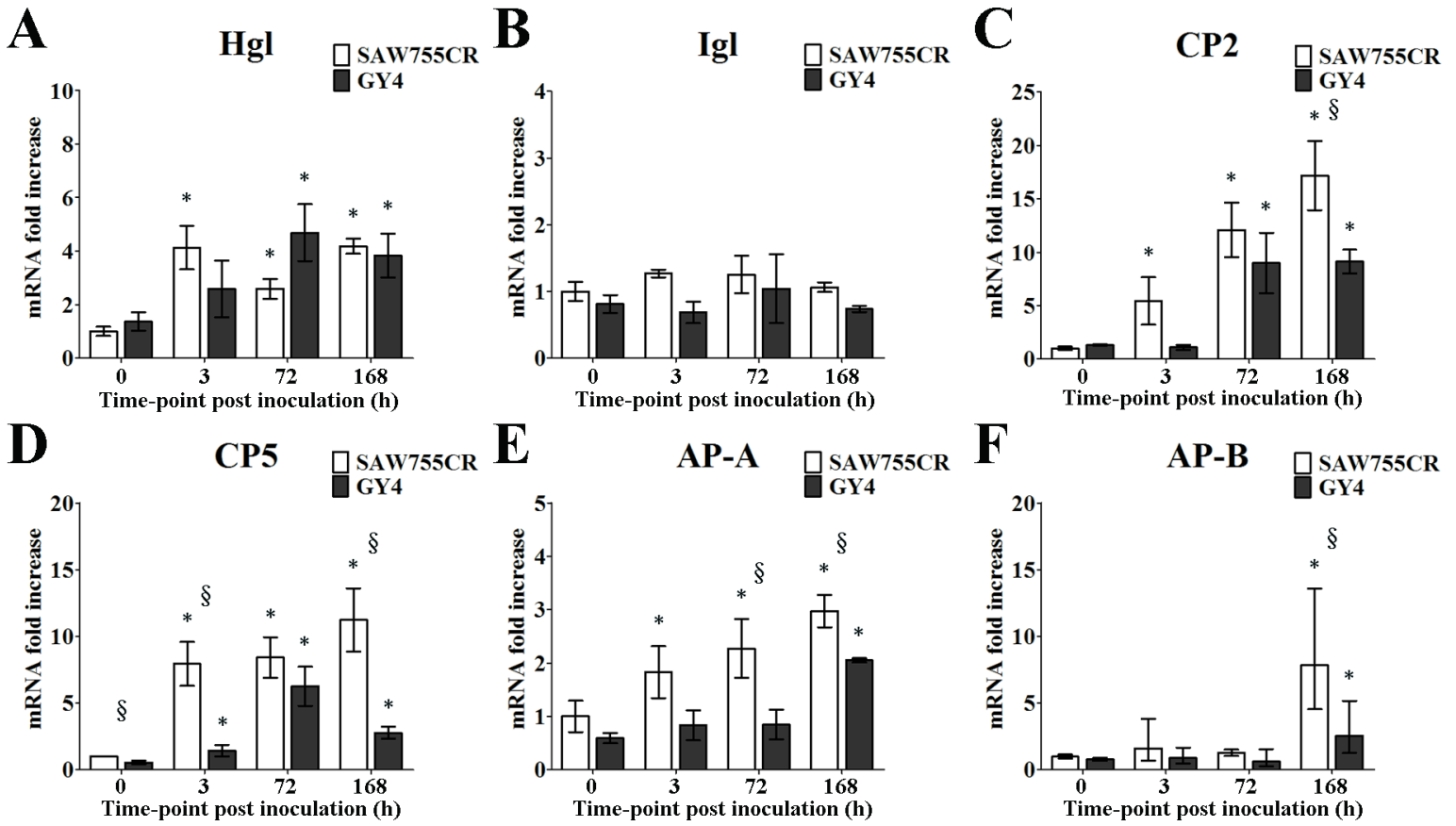

Fig 5. Quantitative real-time PCR assays of expression of $\mathrm{Hgl}(\mathrm{A}), \mathrm{Igl}(\mathrm{B}), \mathrm{CP} 2$ (C), CP5 (D), AP-A (E) and AP-B (F) from $E$. histolytica or E. nuttalli in ALAs of hamsters. Expression levels of genes for virulence factors of trophozoites in liver tissues from hamsters inoculated with $E$. nuttalli GY4 trophozoites are shown as $2-\Delta \Delta \mathrm{Ct}$ for the target gene relative to ameba $\beta$-actin and normalized with the corresponding values from E. histolytica at $0 \mathrm{~h}, 3 \mathrm{~h}, 72 \mathrm{~h}, 168 \mathrm{~h}$ post-inoculation. Y axes are numbers correspond to the fold increase over 1.0, assigned to $0 \mathrm{~h}$ with E. histolytica. Error bars are standard errors of the mean calculated from three independent replicates. The abscissa shows the time post-inoculation. ${ }^{*} \mathrm{P}<0.05$ vs. $0 \mathrm{~h}, \S \mathrm{P}<0.05$ for E. nuttalli GY4 vs. E. histolytica SAW755CR.

https://doi.org/10.1371/journal.pntd.0006216.g005 
A

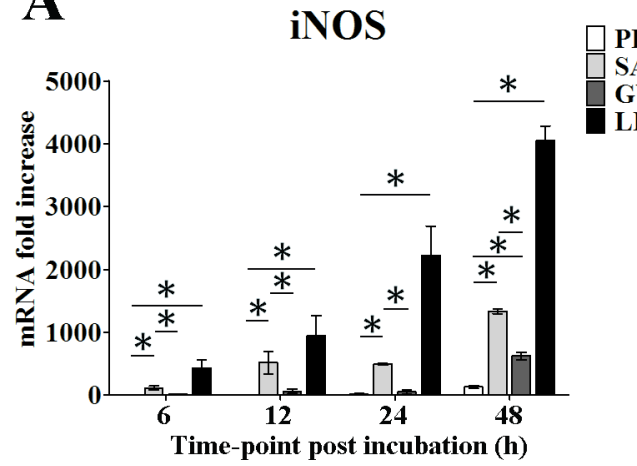

C

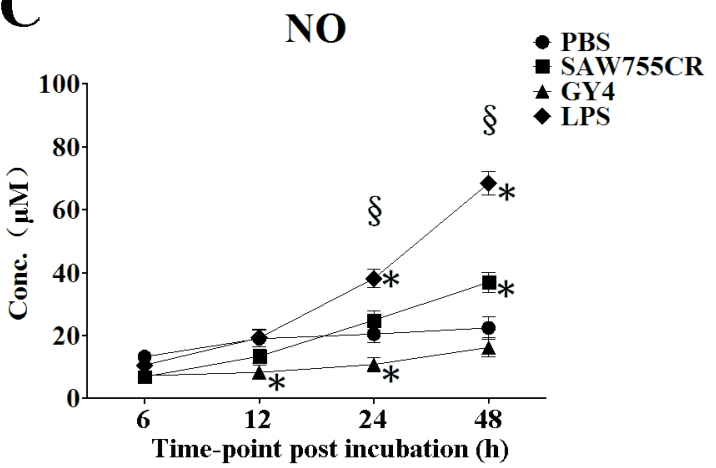

$\mathbf{E}$

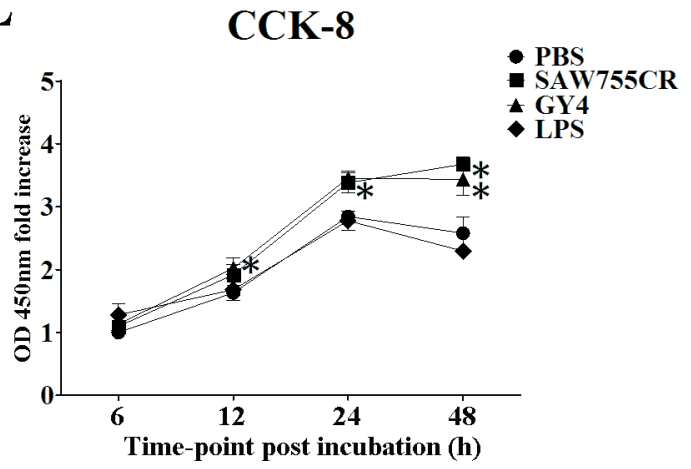

B

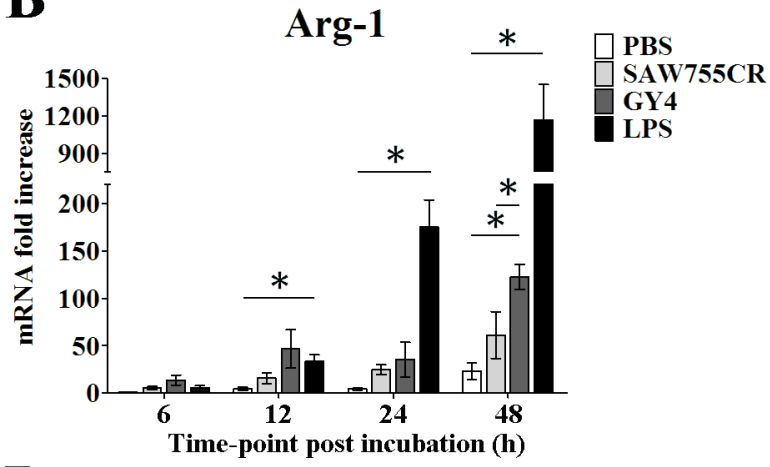

D

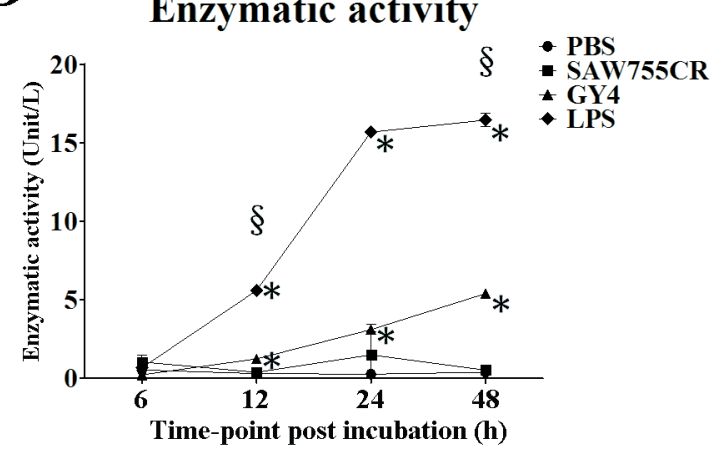

Fig 6. Polarization of RAW264.7 cells stimulated by trophozoite lysates in vitro. (A,B) Quantitative real-time PCR assays of iNOS and Arg-1 genes induced by PBS, trophozoite lysates or LPS in RAW264.7 cells. Expression levels of iNOS (A) and Arg-1 (B) are shown as 2$\Delta \Delta \mathrm{Ct}$ for the target gene relative to $\beta$-actin and normalized with corresponding values in the PBS group. $\mathrm{Y}$ axes are numbers correspond to the fold increase over 1.0, assigned to the PBS group. ${ }^{*} \mathrm{P}<0.05$. (C) NO production in RAW264.7 cells. NO $(\mu \mathrm{M})$ in culture supernatant of RAW264.7 cells stimulated by PBS, trophozoite lysates or LPS for $6 \mathrm{~h}, 12 \mathrm{~h}, 24 \mathrm{~h}$ and $48 \mathrm{~h}$ was measured by a Griess assay. (D) Arginase activity of RAW264.7 cells. Arginase activity (unit/L) was measured in RAW264.7 cell lysates stimulated by PBS, trophozoite lysates or LPS for $6 \mathrm{~h}, 12 \mathrm{~h}, 24 \mathrm{~h}$ and $48 \mathrm{~h}$. (E) Cell proliferation assay of RAW264.7 cells. Cell proliferation was measured using a CCK-8 kit at $6 \mathrm{~h}, 12 \mathrm{~h}$, $24 \mathrm{~h}$ and $48 \mathrm{~h}$ after stimulation with PBS, trophozoite lysates or LPS. The Y-axis shows the optical density (OD) of the test well minus the blank well. * $\mathrm{P}<0.05$ vs. PBS control in $\mathrm{C}$ to $\mathrm{E}, \S \mathrm{P}<0.05$ for $E$. nuttalli $\mathrm{GY} 4$ vs. E. histolytica SAW755CR in C and D.

https://doi.org/10.1371/journal.pntd.0006216.g006

stable oxidized product of $\mathrm{NO}$ in the cell culture supernatants was determined by the Griess assay. Nitrate was increased by stimulation with lysate of E. histolytica at $24 \mathrm{~h}(24.8 \mu \mathrm{M})$ and $48 \mathrm{~h}(36.9 \mu \mathrm{M})(\mathrm{Fig} 6 \mathrm{C})$. The effect of trophozoite lysates on arginase activity was also examined. Arginase activity induced by lysates of E. histolytica and E. nuttalli, and LPS was increased at 24 $\mathrm{h}$ and $48 \mathrm{~h}$, with lysate of $E$. nuttalli inducing higher arginase activity (5.4 unit/L) than that of $E$. histolytica at $48 \mathrm{~h}$ (Fig 6D). These results indicate that secretory proteins of Entamoeba play important roles in the polarization balance of macrophages. 

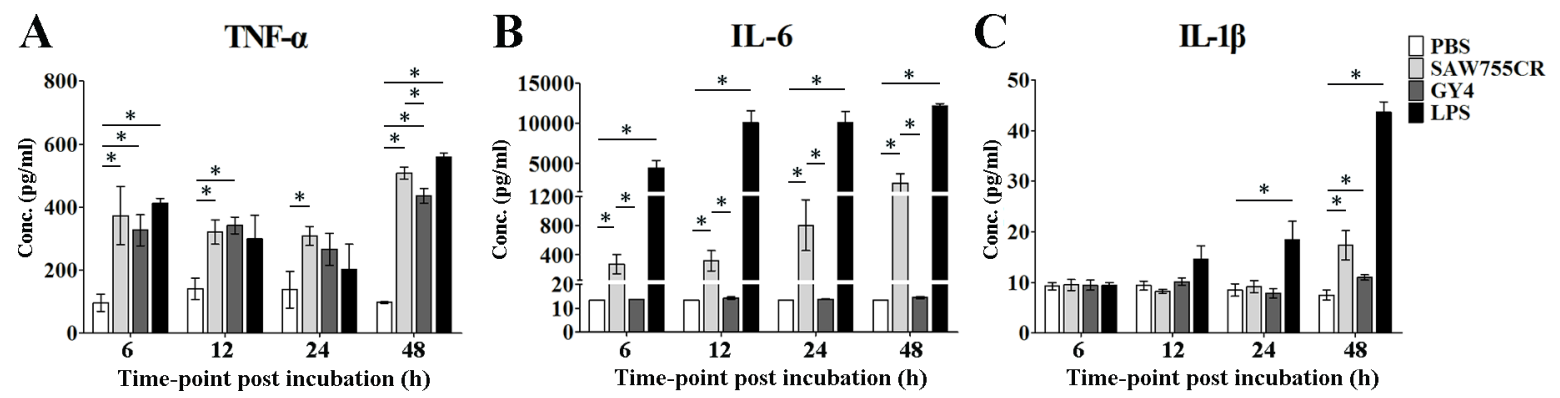

Fig 7. Luminex multiplex immunoassay of TNF- $\alpha$ (A), IL-6 (B) and IL-1ß (C) in culture supernatant of RAW264.7 cells after stimulation. Raw264.7 cells were stimulated by PBS, trophozoite lysates or LPS for $6 \mathrm{~h}, 12 \mathrm{~h}, 24 \mathrm{~h}$ and $48 \mathrm{~h}$. Supernatants were harvested and inflammatory cytokine concentrations $(\mathrm{pg} / \mathrm{ml})$ were measured. ${ }^{*} \mathrm{P}<0.05$.

https://doi.org/10.1371/journal.pntd.0006216.g007

A cell proliferation assay indicated that RAW264.7 cells were capable of proliferation after stimulation with trophozoite lysates of E. histolytica and E. nuttalli. An additional $33 \%$ to $42 \%$ proliferation of RAW264.7 cells occurred in comparison with PBS-stimulated cells at $48 \mathrm{~h}$. There was no significant difference between lysates of E. histolytica and E. nuttalli (Fig 6E).

\section{Increased secretion of cytokines in RAW264.7 cells after stimulation}

Cytokine expression of RAW264.7 cells was determined using a Luminex multiplex immunoassay after stimulation with PBS, trophozoite lysate of E. histolytica or E. nuttalli, and LPS. Lysate of $E$. histolytica induced a significant increase in TNF- $\alpha(507.9 \mathrm{pg} / \mathrm{ml}), \mathrm{IL}-6(2573.0 \mathrm{pg} /$ $\mathrm{ml})$ and IL-1 $\beta(17.3 \mathrm{pg} / \mathrm{ml})$ at $48 \mathrm{~h}$. Lysate of E. nuttalli also caused a significant increase in TNF- $\alpha(435.5 \mathrm{pg} / \mathrm{ml})$ at $48 \mathrm{~h}$, but had no significant effect on IL-6 and IL-1 $\beta$ (Fig 7). These results are consistent with the lower expression levels of IL- 6 and IL- $1 \beta$ with E. nuttalli GY4 in the hamster ALA model.

\section{Discussion}

The aim of this study was to determine the histopathological features of ALAs that regulate host inflammatory immune responses following their interaction with parasites and to examine whether these features differ between E. nuttalli and E. histolytica. Our data show that both E. nuttalli and E. histolytica cause liver abscesses with a clear boundary between the abscess and normal tissue. Interestingly, lesions in hamster differed between E. nuttalli and E. histolytica, including the size of the abscess and inflammatory cell infiltration region. The ability of trophozoites to produce a liver abscess in hamsters also differs among strains of $E$. histolytica and E. dispar, and the SAW755 strain of E. histolytica used in this study is a highly virulent strain. Even in hamsters inoculated with E. nuttalli trophozoites, lethal cases occurred within 7 days using the NASA06 strain [10], and in hamsters inoculated with the E. nuttalli SSS212, the mean abscess size was $>50 \%$ of the liver [12]. In liver tissue sections, the necrotic area with inflammatory reactions was highly extended. Therefore, the virulency of the E. nuttalli GY4 strain used in the present study may have been relatively low.

Tissue destruction during ALA formation is generally attributable to both the cytotoxicity of trophozoites and the resultant host inflammatory immune response [29]. A typical amebic lesion is characterized by a necrotic zone with edges consisting of cellular debris and inflammatory cell infiltration [30]. Such necrosis is produced by virulence factors of trophozoites, such as galactose/ $\mathrm{N}$-acetylgalactosamine lectin (Gal/GalNac lectin), APs and CPs [29-33]. In the present study, the expression levels of virulence factors of trophozoites in tissue was higher than that of axenically cultured trophozoites, but the levels of major CPs and APs differed 
between the two strains, with lower levels in E. nuttalli. Immunopathological effects also contribute to tissue destruction during liver abscess formation in the hamster model. The host inflammatory response suppresses invasive trophozoites, but also leads to severe tissue damage. During this infectious process, multiple types of inflammatory cells are recruited to the infected liver of hamsters. Infiltrating neutrophils are predominant in inflammatory regions in the initial phase of invasive liver amebic infection, followed by macrophages that accumulate rapidly during abscess formation.

Evidence from in vivo and in vitro studies suggests that macrophage-mediated anti-ameba activity is a major mode of host defense against $E$. histolytica infections, and has essential functions throughout ALA formation [34]. When pathogens attack, naïve macrophages can be polarized in a direction to classical activated (M1) macrophages that strongly express iNOS, which produces $\mathrm{NO}$ through catabolism of arginine, subsequently causing proinflammatory effects and tissue damage [35, 36]. During abscess formation, M1 macrophages release NO into infected tissue, and NO combined with toxic products from the oxidative burst then kill trophozoites. The macrophage-mediated anti-ameba activity is inhibited by arginase in a dosedependent manner through competition with iNOS that depletes the common substrate, Larginine [37, 38]. Macrophages can also be polarized into alternatively activated (M2) macrophages and induce Arg-1, which competes with iNOS by degrading arginine into ornithine and polyamines, giving rise to macrophages with anti-inflammatory effects and tissue repair functions $[35,36,39]$. The present study showed that $E$. nuttalli GY4 induced small liver abscesses at $168 \mathrm{~h}$ after inoculation compared with large abscesses driven by E. histolytica SAW755CR. Moreover, infiltration of inflammatory cells remained lower in abscess lesions of E. nuttalli compared to those caused by E. histolytica.

In amebic liver lesions, secretion of Gal/GalNac lectin, APs and CPs by trophozoites also results in destruction of neutrophils and liberation of their toxic products, which may play an important role in enlargement of abscess lesions [29, 30]. Immunosuppressive and tissue repair functions play critical roles in control of inflammation by producing anti-inflammatory mediators [36, 39]. In this study, both Entamoeba species caused increased levels of iNOS in liver lesions of hamsters and decreased arginine at the early stage of ALA formation, indicating elevation of M1 macrophages, which are involved in host defense and tissue damage. Significantly, the level of arginine increased with E. nuttalli at $168 \mathrm{~h}$ after trophozoite inoculation, which suggests greater elevation of M2 macrophages compared with E. histolytica infection. The increased proportion of M2 macrophages in liver abscess lesions might attenuate tissue damage through accelerated tissue repair, and this might explain the smaller abscesses and milder liver tissue damage in the animal model infected with E. nuttalli.

There are several key factors in macrophage polarization during infection, with pathogens and their virulence proteins being the fundamental regulators [39-41]. The current study indicated that proteins secreted by both Entamoeba species were able to induce macrophage polarization and skew differentiation towards M1 or M2 phenotypes. With E. histolytica, the macrophage polarization skewed towards the M1 phenotype, as shown by the significant increase in iNOS expression and multiple proinflammatory cytokines, such as TNF- $\alpha$, IL-1 and IL-6, exerting immunoregulatory roles during infection. With E. nuttalli, the polarization trend of macrophages was not as clear, based on the lower levels of iNOS and cytokines and higher production of arginine, compared to E. histolytica infection. These results suggest an equilibrium in macrophage polarization. Several studies have shown amebicidal activity of macrophages mediated by iNOS mRNA expression and NO production [30,42, 43]. There is also evidence of direct macrophage activity by amebic virulence factors, and E. nuttalli secreted fewer virulence factors than E. histolytica based on protein profiles. Taken together, these data indicate that virulence factors inducing macrophage polarization in hamster liver lesions 
switch to a protective M2 phenotype from a destructive M1 phenotype, leading to decreased NO production, which reduces immunopathological tissue damage.

T-cell cytokine responses can be divided into different classes based on the combination of cytokines produced. Th1 cells secrete cytokines including IL-2, IFN- $\gamma$ and TNF- $\beta$ that promote differentiation and activity of macrophages and cytotoxic $\mathrm{T}$ cells, and lead primarily to a cytotoxic immune response. In contrast, the Th2 cytokine response is characterized by IL-4, IL-5, IL-6, IL-9 and IL-10 production [44]. These cytokines, the levels of which correlate with the degree of tissue damage, are released by attacked host cells or effector cells. IFN- $\gamma$ is a suppressive cytokine that can clear the parasite [45]. In the present study, there was no significant increase in IFN- $\gamma$ during ALA development in hamsters, perhaps suggesting that persistent progression of lesions facilitates invasive amebiasis. In contrast, TNF- $\alpha$ and IL-6, which are inflammatory factors, were strongly sustained and expressed during progression of tissue damage. Macrophages were clearly the major effector cells secreting these cytokine mediators. M1 macrophages secreted proinflammatory cytokines, including TNF- $\alpha$, IL- $1 \beta$ and IL- 6 , which activate phagocytes to kill pathogens, but also cause tissue damage [46, 47]. The results of immunohistochemistry and qRT-PCR indicated that the levels of multiple cytokines increased during ALA formation. These results suggest that macrophage polarization might profoundly affect the degree of tissue damage in ALA formation.

At the early stage of infection, TNF- $\alpha$, IL- $1 \beta$ and IL- 6 showed an increasing trend with both Entamoeba species, but with higher levels with E. histolytica than with E. nuttalli. The increased TNF- $\alpha$ and IL- 6 during amebic tissue damage results in activation of macrophages to release NO and thereby exert an anti-inflammatory effect. Our data show that macrophage polarization by E. histolytica SAW755CR induced greater upregulation of iNOS expression at the transcriptional level, resulting in a higher proportion of M1 polarized macrophages, which then secreted higher levels of proinflammatory cytokines and aggravated amebic tissue damage. The released TNF- $\alpha$ and IL-1 $\beta$ feedback to further skew macrophage differentiation towards the M1 phenotype. Consequently, small multiple abscesses merge with each other and coalesce to form large single abscesses after infection with E. histolytica SAW755CR. M2 macrophages generally have high levels of mannose receptors and scavenger receptors, and play important roles in polarized Th2 reactions. For example, M2 macrophages promote the encapsulation and killing of parasites and have immunoregulatory and anti-inflammatory functions [48]. This macrophage population is also thought to play a critical role in negative regulation of host protective immunity against microbial infections. Thus, M2 macrophages modulate expression of anti-inflammatory cytokines such as MRC or transforming growth factor, and thereby modulate suppression of tissue inflammation and enhance tissue repair [49]. In E. nuttalli infection, expression levels of TNF- $\alpha$ and IL-1 $\beta$ decreased at $168 \mathrm{~h}$ after inoculation, whereas expression of MRC was upregulated with the same trend as that of Arg-1. The downregulation of TNF- $\alpha$ and IL- $1 \beta$ suggests that tissue damage might be slowed in E. nuttalli infection. Macrophage polarization tends to reach an equilibrium with the increase in the M2 phenotype. Repair-associated factors begin to take effect and inhibit ALA formation and development. Finally, this leads to formation of multiple small abscesses that are incapable of coalescing into larger lesions, consistent with the finding that $E$. nuttalli GY4 forms smaller liver abscesses than E. histolytica SAW755. Thus, our results show that differential secretion of amebic virulence factors in E. nuttalli infection may trigger lower cytokine secretion and promote polarization of macrophages towards a M1/M2 balance.

In consideration of intestinal immunity that is the first line of defense against amoeba trophozoites, a critical aspect in Entamoeba pathogenesis is to overcome the colonic epithelial barrier [50-53]. The intestinal bacterial microbiota is another important factor that influence the pathogenesis of E. histolytica. This could be interrelated to direct ingestion of intestinal 
bacteria that increase the expression of virulence proteins of $E$. histolytica [54-58]. The bacteria could also alter the immune status of host intestine to prevent or promote amoebiasis. For instance, the increasing of IL-23, IL-17, dendritic cells and neutrophil induced by segmented filamentous bacterium in the cecum mediated protection from E. histolytica $[59,60]$. E. nuttalli trophozoites may elicit ALA formation with intense inflammatory reaction in human if the parasites translocate to liver. However, E. nuttalli is probably not adapted to intestinal microenvironment of human and unable to invade beyond the colonic epithelial barrier of human under natural conditions.

There is unambiguous evidence of an intense acute inflammatory reaction in hamster liver in infection by both Entamoeba species, but no evidence showing that these events in hamster liver also occur in human liver. Moreover, it is unknown whether E. nuttalli trophozoites produce intestinal ulcer in human and non-human primates. Additionally, as well known in genetic restriction, a $\mathrm{T}$-cell receptor recognizes a particular antigenic peptide presented by a specific histocompatibility complex (MHC) molecule, and this interaction is associated with susceptibility or resistance to pathogen infection [61-64]. For instance, highly polymorphic HLA genes have an enormous capacity to bind to viral peptides associated with HBV infection [65] and a single MHC supertype confers qualitative resistance to Plasmodium relictum infections in avian malaria [66]. Consequently, host MHC molecule may also play a key role in determination of host susceptibility to E. nuttalli.

In conclusion, histopathological features and expression levels of proinflamatory factors in ALAs formed by E. nuttalli were identified in this study. The results also suggest that the difference of tissue damage in infection by E. histolytica and E. nuttalli is due to the levels of secretion of various cytokines, regardless of the extent of macrophage polarization. In any event, both Entamoeba species induced intense acute inflammatory reactions in liver of hamsters after infection.

\section{Supporting information}

S1 Fig. Immunohistochemical staining of liver sections $3 \mathrm{~h}(\mathrm{~A})$ or $6 \mathrm{~h}(\mathrm{~B})$ after intrahepatic inoculation. Liver of hamsters was inoculated with $1 \times 10^{6}$ of trophozoites from E. histolytica SAW755CR strain or E. nuttalli GY4 strain. $3 \mathrm{~h}$ or $6 \mathrm{~h}$ later, the liver section was stained immunohistochemically with polyclonal antibodies for IFN- $\gamma$, TNF- $\alpha$, IL-1 $\beta$ and IL-6. I: Control group, II: SAW755CR group, III: GY4 group.

(PDF)

S2 Fig. Immunohistochemical staining of liver sections $12 \mathrm{~h}$ (A) or $24 \mathrm{~h}$ (B) after intrahepatic inoculation. Liver of hamsters was inoculated with $1 \times 10^{6}$ of trophozoites from E. histolytica SAW755CR strain or E. nuttalli GY4 strain. $12 \mathrm{~h}$ or $24 \mathrm{~h}$ later, the liver section was stained immunohistochemically with polyclonal antibodies for IFN- $\gamma$, TNF- $\alpha$, IL-1 $\beta$ and IL-6. I: Control group, II: SAW755CR group, III: GY4 group.

(PDF)

S3 Fig. Immunohistochemical staining of liver sections $48 \mathrm{~h}$ (A) or $72 \mathrm{~h}$ (B) after intrahepatic inoculation. Liver of hamsters was inoculated with $1 \times 10^{6}$ of trophozoites from E. histolytica SAW755CR strain or E. nuttalli GY4 strain. $48 \mathrm{~h}$ or $72 \mathrm{~h}$ later, the liver section was stained immunohistochemically with polyclonal antibodies for IFN- $\gamma$, TNF- $\alpha$, IL-1 $\beta$ and IL-6. I: Control group, II: SAW755CR group, III: GY4 group.

(PDF)

S1 Text. The nucleotide sequences of virulence protein genes of $E$. nuttalli GY4 strain. (DOCX) 


\section{Author Contributions}

Conceptualization: Xunjia Cheng.

Formal analysis: Meng Feng.

Funding acquisition: Hiroshi Tachibana, Xunjia Cheng.

Investigation: Yue Guan, Meng Feng, Xiangyang Min, Hang Zhou, Yongfeng Fu, Xunjia Cheng.

Methodology: Xunjia Cheng.

Project administration: Hiroshi Tachibana, Xunjia Cheng.

Writing - original draft: Yue Guan, Meng Feng, Xunjia Cheng.

Writing - review \& editing: Hiroshi Tachibana, Xunjia Cheng.

\section{References}

1. Stanley SL Jr. Amoebiasis. Lancet. 2003; 361(9362):1025-34. Epub 2003/03/28. https://doi.org/10. 1016/S0140-6736(03)12830-9 PMID: 12660071

2. Ximénez $C$, Morán $P$, Rojas $L$, Valadez $A$, Gómez A. Reassessment of the epidemiology of amebiasis: state of the art. Infect Genet Evol. 2009; 9(6):1023-32. https://doi.org/10.1016/j.meegid.2009.06.008 PMID: 19540361

3. Wertheim HF, Horby P, Woodall JP. Atlas of human infectious diseases. UK: Blackwell Publishing; 2012.

4. Arnold BF, van der Laan MJ, Hubbard AE, Steel C, Kubofcik J, Hamlin KL, Moss DM, Nutman TB, Priest $\mathrm{JW}$, Lammie PJ. Measuring changes in transmission of neglected tropical diseases, malaria, and enteric pathogens from quantitative antibody levels. PLoS Negl Trop Dis. 2017; 11(5):e0005616. https://doi.org/10.1371/journal.pntd.0005616 PMID: 28542223

5. Sahimin N, Lim YA, Ariffin F, Behnke JM, Lewis JW, Mohd Zain SN. Migrant workers in Malaysia: current implications of sociodemographic and environmental characteristics in the transmission of intestinal parasitic infections. PLoS Negl Trop Dis. 2016; 10(11):e0005110. https://doi.org/10.1371/journal. pntd.0005110 PMID: 27806046

6. Zaki M, Meelu P, Sun W, Clark CG. Simultaneous differentiation and typing of Entamoeba histolytica and Entamoeba dispar. J Clin Microbiol. 2002; 40(4):1271-1276. https://doi.org/10.1128/JCM.40.4 1271-1276.2002 PMID: 11923344

7. Tachibana H, Yanagi T, Pandey K, Cheng XJ, Kobayashi S, Sherchand JB, Kanbara H. An Entamoeba sp. strain isolated from rhesus monkey is virulent but genetically different from Entamoeba histolytica. Mol Biochem Parasitol. 2007; 153(2):107-114. https://doi.org/10.1016/j.molbiopara.2007.02.006 PMID: 17403547

8. Feng M, Cai J, Min X, Fu Y, Xu Q, Tachibana H, Cheng X. Prevalence and genetic diversity of Entamoeba species infecting macaques in southwest China. Parasitol. Res. 2013; 112(4):1529-1536. https://doi.org/10.1007/s00436-013-3299-1 PMID: 23354942

9. Guan Y, Feng M, Cai J, Min X, Zhou X, Xu Q, Tan N, Cheng X, Tachibana H. Comparative analysis of genotypic diversity in Entamoeba nuttalli isolates from Tibetan macaques and rhesus macaques in China. Infect Genet Evol. 2016; 38:126-31. https://doi.org/10.1016/j.meegid.2015.12.014 PMID: 26723919

10. Tachibana H, Yanagi T, Akatsuka A, Kobayashi S, Kanbara H, Tsutsumi V. Isolation and characterization of a potentially virulent species Entamoeba nuttalli from captive Japanese macaques. Parasitology 2009; 136(10):1169-1177. https://doi.org/10.1017/S0031182009990576 PMID: 19635174

11. Tachibana H, Yanagi T, Lama C, Pandey K, Feng M, Kobayashi S, Sherchand JB. Prevalence of Entamoeba nuttalli infection in wild rhesus macaques in Nepal and characterization of the parasite isolates. Parasitol Int.2013; 62(2):230-235. https://doi.org/10.1016/j.parint.2013.01.004 PMID: 23370534

12. Tachibana H, Yanagi T, Feng M, Bandara KB, Kobayashi S, Cheng X, Hirayama K, Rajapakse RP. Isolation and molecular characterization of Entamoeba nuttalli strains showing novel isoenzyme patterns from wild toque macaques in Sri Lanka. J Eukaryot Microbiol. 2016; 63(2):171-180. https://doi.org/10 1111/jeu.12265 PMID: 26333681

13. Tuda J, Feng M, Imada M, Kobayashi S, Cheng X, Tachibana H. Identification of Entamoeba polecki with unique 18S rRNA gene sequences from celebes crested macaques and pigs in Tangkoko nature 
reserve, North Sulawesi, Indonesia. J Eukaryot Microbiol. 2016; 63(5):572-577. https://doi.org/10. 1111/jeu.12304 PMID: 26861809

14. Takano J, Tachibana H, Kato M, Narita T, Yanagi T, Yasutomi Y, Fujimoto K. DNA characterization of simian Entamoeba histolytica-like strains to differentiate them from Entamoeba histolytica. Parasitol Res. 2009; 105(4):929-937. https://doi.org/10.1007/s00436-009-1480-3 PMID: 19471966

15. Levecke B, Dreesen L, Dorny P, Verweij JJ, Vercammen F, Casaert S, Vercruysse J, Geldhof P. Molecular identification of Entamoeba spp. in captive nonhuman primates. J Clin Microbiol. 2010; 48 (8):2988-2990. https://doi.org/10.1128/JCM.00013-10 PMID: 20573870

16. Levecke B, Dorny P, Vercammen F, Visser LG, van Esbroeck M, Vercruysse J, Verweij JJ. Transmission of Entamoeba nuttalli and Trichuris trichiura from nonhuman primates to humans. Emerg Infect Dis. 2015; 21(10):1871-1872. https://doi.org/10.3201/eid2110.141456 PMID: 26402309

17. Suzuki J, Kobayashi S, Murata R, Yanagawa Y, Takeuchi T. Profiles of a pathogenic Entamoeba histolytica-like variant with variations in the nucleotide sequence of the small subunit ribosomal RNA isolated from a primate (De Brazza's guenon). J Zoo Wildl Med. 2007; 38(3):471-474. https://doi.org/10.1638/ 2006-0068.1 PMID: 17939358

18. Suzuki J, Kobayashi S, Murata R, Tajima H, Hashizaki F, Yanagawa Y, Takeuchi T. A survey of amoebic infections and differentiation of an Entamoeba histolytica-like variant (JSK2004) in nonhuman primates by a multiplex polymerase chain reaction. J Zoo Wildl Med. 2008; 39(3):370-379. https://doi.org/ 10.1638/2007-0171.1 PMID: 18816999

19. Tsutsumi V, Mena-Lopez R, Anaya-Velazquez F, Martinez-Palomo A. Cellular bases of experimental amebic liver abscess formation. Am J Pathol. 1984; 117(1):81-91. PMID: 6385728

20. Tsutsumi V, Shibayama M. Experimental amebiasis: a selected review of some in vivo models. Arch Med Res. 2006; 37(2):210-220. https://doi.org/10.1016/j.arcmed.2005.09.011 PMID: 16380321

21. Kobayashi S, Imai E, Haghighi A, Khalifa SA, Tachibana H, Takeuchi T. Axenic cultivation of Entamoeba dispar in newly designed yeast extract-iron-gluconic acid-dihydroxyacetone-serum medium. J Parasitol. 2005; 91(1):1-4. https://doi.org/10.1645/GE-3386 PMID: 15856863

22. Min X, Feng M, Guan $Y$, Man S, Fu Y, Cheng X, Tachibana H. Evaluation of the C-terminal fragment of Entamoeba histolytica Gal/GalNAc lectin intermediate subunit as a vaccine candidate against amebic liver abscess. PLoS Negl Trop Dis. 2016; 10(1):e0004419. https://doi.org/10.1371/journal.pntd. 0004419 PMID: 26824828

23. Cheng $\mathrm{XJ}$, Tachibana $\mathrm{H}$. Protection of hamsters from amebic liver abscess formation by immunization with the 150- and 170-kDa surface antigens of Entamoeba histolytica. Parasitol Res. 2001; 87(2):12630. PMID: 11206109

24. Sato Y, Harada K, Ozaki S, Furubo S, Kizawa K, Sanzen T, Yasoshima M, Ikeda H, Sasaki M, Nakanuma Y. Cholangiocytes with mesenchymal features contribute to progressive hepatic fibrosis of the polycystic kidney rat. Am J Pathol. 2007; 171(6):1859-1871. https://doi.org/10.2353/ajpath.2007. 070337 PMID: 18055542

25. Stanley SL Jr. Progress towards development of a vaccine for amebiasis. Clin Microbiol Rev. 1997; 10 (4):637-649. PMID: 9336666

26. Huston CD, Petri WA Jr. Host-pathogen interaction in amebiasis and progress in vaccine development. Eur J Clin Microbiol Infect Dis. 1998; 17(9):601-614. PMID: 9832261

27. Kovács M, Kiss A, Gönczi M, Miskolczi G, Seprényi G, Kaszaki J, Kohr MJ, Murphy E, Végh Á. Effect of sodium nitrite on ischaemia and reperfusion-induced arrhythmias in anaesthetized dogs: is protein Snitrosylation involved? PLoS One. 2015; 10(4):e0122243. https://doi.org/10.1371/journal.pone. 0122243 PMID: 25909651

28. Kiss A, Juhász L, Seprényi G, Kupai K, Kaszaki J, Végh A. The role of nitric oxide, superoxide and peroxynitrite in the anti-arrhythmic effects of preconditioning and peroxynitrite infusion in anaesthetized dogs. Br J Pharmacol. 2010; 160(5):1263-1272. https://doi.org/10.1111/j.1476-5381.2010.00774.x PMID: 20590618

29. Moonah SN, Jiang NM, Petri WA Jr. Host immune response to intestinal amebiasis. PLoS Pathog. 2013; 9(8):e1003489. https://doi.org/10.1371/journal.ppat.1003489 PMID: 23990778

30. Helk E, Bernin H, Ernst T, Ittrich H, Jacobs T, Heeren J, Tacke F, Tannich E, Lotter H. TNFa-mediated liver destruction by Kupffer cells and Ly6Chi monocytes during Entamoeba histolytica infection. PLoS Pathog. 2013; 9(1):e1003096. https://doi.org/10.1371/journal.ppat.1003096 PMID: 23300453

31. Petri WA Jr., Haque R, Mann BJ. The bittersweet interface of parasite and host: lectin-carbohydrate interactions during human invasion by the parasite Entamoeba histolytica. Annu Rev Microbiol. 2002; 56:39-64. https://doi.org/10.1146/annurev.micro.56.012302.160959 PMID: 12142490 
32. Petri WA Jr., Schnaar RL. Purification and characterization of galactose- and N-acetylgalactosaminespecific adhesin lectin of Entamoeba histolytica. Methods Enzymol. 1995; 253:98-104. PMID: 7476421

33. Lopez-Vancell R, Montfort I, Perez-Tamayo R. Galactose-specific adhesin and cytotoxicity of Entamoeba histolytica. Parasitol Res. 2000; 86(3):226-31. PMID: 10726993

34. Mortimer L, Chadee K. The immunopathogenesis of Entamoeba histolytica. Exp Parasitol. 2010; 126 (3):366-380. https://doi.org/10.1016/j.exppara.2010.03.005 PMID: 20303955

35. Martinez FO, Gordon S. The M1 and M2 paradigm of macrophage activation: time for reassessment. F1000Prime Rep. 2014; 6:13. https://doi.org/10.12703/P6-13 PMID: 24669294

36. Akira S, Misawa T, Satoh T, Saitoh T. Macrophages control innate inflammation. Diabetes Obes Metab. 2013; 15(Suppl 3):10-18. https://doi.org/10.1111/dom.12151 PMID: 24003916

37. Lin JY, Chadee K. Macrophage cytotoxicity against Entamoeba histolytica trophozoites is mediated by nitric oxide from L-arginine. J Immunol. 1992; 148(12):3999-4005. PMID: 1318338

38. Badirzadeh A, Taheri T, Taslimi Y, Abdossamadi Z, Heidari-Kharaji M, Gholami E, Sedaghat B, Niyyati M, Rafati S. Arginase activity in pathogenic and non-pathogenic species of Leishmania parasites. PLoS Negl Trop Dis. 2017; 11(7):e0005774. https://doi.org/10.1371/journal.pntd.0005774 PMID: 28708893

39. Tomioka H, Tatano Y, Maw WW, Sano C, Kanehiro Y, Shimizu T. Characteristics of suppressor macrophages induced by mycobacterial and protozoal infections in relation to alternatively activated M2 macrophages. Clin Dev Immunol. 2012; 2012:635451. https://doi.org/10.1155/2012/635451 PMID: 22666284

40. Zhu J, Xu Z, Chen X, Zhou S, Zhang W, Chi Y, Li W, Song X, Liu F, Su C. Parasitic antigens alter macrophage polarization during Schistosoma japonicum infection in mice. Parasit Vectors. 2014; 7:122. https://doi.org/10.1186/1756-3305-7-122 PMID: 24666892

41. Kim EM, Kwak YS, Yi MH, Kim JY, Sohn WM, Yong TS. Clonorchis sinensis antigens alter hepatic macrophage polarization in vitro and in vivo. PLoS Negl Trop Dis. 2017; 11(5):e0005614. https://doi.org/10. 1371/journal.pntd.0005614 PMID: 28542159

42. Ivory $\mathrm{CP}$, Prystajecky $\mathrm{M}$, Jobin $\mathrm{C}$, Chadee $\mathrm{K}$. Toll-like receptor 9-dependent macrophage activation by Entamoeba histolytica DNA. Infect Immun. 2008; 76(1):289-297. https://doi.org/10.1128/IAI.01217-07 PMID: 17984204

43. Begum S, Quach J, Chadee K. Immune evasion mechanisms of Entamoeba histolytica: progression to disease. Front Microbiol. 2015; 6:1394. https://doi.org/10.3389/fmicb.2015.01394 PMID: 26696997

44. Mosmann TR, Coffman RL. TH1 and TH2 cells: different patterns of lymphokine secretion lead to different functional properties. Annual review of immunology. 1989; 7:145-73. https://doi.org/10.1146/ annurev.iy.07.040189.001045 PMID: 2523712

45. Moraes LC, França EL, Pessoa RS, Fagundes DL, Hernandes MG, Ribeiro VP, Gomes MA, HonorioFrança AC. The effect of IFN- $\gamma$ and TGF- $\beta$ in the functional activity of mononuclear cells in the presence of Entamoeba histolytica. Parasit Vectors. 2015; 8:413. https://doi.org/10.1186/s13071-015-1028-6 PMID: 26249205

46. He X, Tang R, Sun Y, Wang YG, Zhen KY, Zhang DM, Pan WQ. MicroR-146 blocks the activation of M1 macrophage by targeting signal transducer and activator of transcription 1 in hepatic schistosomiasis. EBio Medicine. 2016; 13:339-347. https://doi.org/10.1016/j.ebiom.2016.10.024 PMID: 27780686

47. Mulder R, Banete A, Basta S. Spleen-derived macrophages are readily polarized into classically activated (M1) or alternatively activated (M2) states. Immunobiology. 2014; 219(10):737-745. https://doi. org/10.1016/j.imbio.2014.05.005 PMID: 24954891

48. Katakura T, Miyazaki M, Kobayashi M, Herndon DN, Suzuki F. CCL17 and IL-10 as effectors that enable alternatively activated macrophages to inhibit the generation of classically activated macrophages. J Immunol. 2004; 172(3):1407-1413. PMID: 14734716

49. Pellicoro A, Ramachandran P, Iredale JP, Fallowfield JA. Liver fibrosis and repair: immune regulation of wound healing in a solid organ. Nat Rev Immunol. 2014; 14(3):181-194. https://doi.org/10.1038/ nri3623 PMID: 24566915

50. Moncada D, Keller K, Chadee K. Entamoeba histolytica cysteine proteinases disrupt the polymeric structure of colonic mucin and alter its protective function. Infect Immun 2003; 71:838-44. https://doi. org/10.1128/IAI.71.2.838-844.2003 PMID: 12540564

51. Espinosa-Cantellano M, Martínez-Palomo A. Pathogenesis of intestinal amebiasis: from molecules to disease. Clin Microbiol Rev 2000; 13:318-31. PMID: 10756002

52. Lejeune M, Moreau F, Chadee K. Prostaglandin E2 produced by Entamoeba histolytica signals via EP4 receptor and alters claudin-4 to increase ion permeability of tight junctions. Am J Pathol 2011; 179:807-18. https://doi.org/10.1016/j.ajpath.2011.05.001 PMID: 21683675 
53. Thibeaux R, Dufour A, Roux P, Bernier M, Baglin AC, Frileux P, Olivo-Marin JC, Guillén N, Labruyère E. Newly visualized fibrillar collagen scaffolds dictate Entamoeba histolytica invasion route in the human colon. Cell Microbiol 2012; 14:609-21. https://doi.org/10.1111/j.1462-5822.2012.01752.x PMID: 22233454

54. Galván-Moroyoqui JM, Del Carmen Domínguez-Robles M, Meza I. Pathogenic bacteria prime the induction of Toll-like receptor signalling in human colonic cells by the Gal/GalNAc lectin Carbohydrate Recognition Domain of Entamoeba histolytica. Int J Parasitol. 2011; 41(10):1101-1112. https://doi.org/ 10.1016/j.ijpara.2011.06.003 PMID: 21787776

55. Cornick S, Chadee K. Entamoeba histolytica: Host parasite interactions at the colonic epithelium. Tissue Barriers. 2017; 5(1):e1283386. https://doi.org/10.1080/21688370.2017.1283386 PMID: 28452682

56. Verma AK, Verma R, Ahuja V, Paul J. Real-time analysis of gut flora in Entamoeba histolytica infected patients of northern India. BMC Microbiol. 2012; 12:183. https://doi.org/10.1186/1471-2180-12-183 PMID: 22913622

57. Morton ER, Lynch J, Froment A, Lafosse S, Heyer E, Przeworski M, Blekhman R, Ségurel L. Variation in rural African gut microbiota is strongly correlated with colonization by Entamoeba and subsistence. PLoS Genet. 2015; 11(11):e1005658. https://doi.org/10.1371/journal.pgen.1005658 PMID: 26619199

58. Chabé M, Lokmer A, Ségurel L. Gut protozoa: friends or foes of the human gut microbiota? Trends Parasitol. 2017; 33(12):925-934. https://doi.org/10.1016/j.pt.2017.08.005 PMID: 28870496

59. Burgess SL, Buonomo E, Carey M, Cowardin C, Naylor C, Noor Z, Wills-Karp M, Petri WA Jr. Bone marrow dendritic cells from mice with an altered microbiota provide interleukin 17A-dependent protection against Entamoeba histolytica colitis. MBio. 2014; 5(6):e01817. https://doi.org/10.1128/mBio. 01817-14 PMID: 25370489

60. Watanabe K, Gilchrist CA, Uddin MJ, Burgess SL, Abhyankar MM, Moonah SN, Noor Z, Donowitz JR, Schneider BN, Arju T, Ahmed E, Kabir M, Alam M, Haque R, Pramoonjago P, Mehrad B, Petri WA Jr. Microbiome-mediated neutrophil recruitment via CXCR2 and protection from amebic colitis. PLoS Pathog. 2017; 13(8):e1006513. https://doi.org/10.1371/journal.ppat.1006513 PMID: 28817707

61. Liu J, Cao S, Peppers G, Kim SH, Graham BS. Clonotype-specific avidity influences the dynamics and hierarchy of virus-specific regulatory and effector CD4(+) T-cell responses. Eur J Immunol. 2014; 44 (4):1058-1068. https://doi.org/10.1002/eji.201343766 PMID: 24510524

62. Sant AJ, Chaves FA, Leddon SA, Tung J. The control of the specificity of CD4 T cell responses: thresholds, breakpoints, and ceilings. Front Immunol. 2013; 4:340. https://doi.org/10.3389/fimmu.2013. 00340 PMID: 24167504

63. Wang Y, Singh NK, Spear TT, Hellman LM, Piepenbrink KH, McMahan RH, Rosen HR, Vander Kooi CW, Nishimura MI, Baker BM. How an alloreactive T-cell receptor achieves peptide and MHC specificity. Proc Natl Acad Sci USA. 2017; 114(24):E4792-E4801. https://doi.org/10.1073/pnas.1700459114 PMID: 28572406

64. Marietta E, Rishi A, Taneja V. Immunogenetic control of the intestinal microbiota. Immunology. 2015; 145(3):313-322. https://doi.org/10.1111/imm.12474 PMID: 25913295

65. Wang L, Zou ZQ, Wang K. Clinical relevance of HLA gene variants in HBV infection. J Immunol Res. 2016; 2016:9069375. https://doi.org/10.1155/2016/9069375 PMID: 27243039

66. Sepil I, Lachish S, Hinks AE, Sheldon BC. Mhc supertypes confer both qualitative and quantitative resistance to avian malaria infections in a wild bird population. Proc Biol Sci. 2013; 280:20130134. https:// doi.org/10.1098/rspb.2013.0134 PMID: 23516242 